\title{
Over-optimism in Forecasts by Official Budget Agencies and its Implications
}

\section{Citation}

Frankel, Jeffrey A. 2011. Over-optimism in Forecasts by Official Budget Agencies and its Implications. Oxford Review of Economic Policy 27(4): 536-562.

\section{Published Version}

http://dx.doi.org/10.1093/oxrep/grr025

\section{Permanent link}

http://nrs.harvard.edu/urn-3:HUL.InstRepos:8705906

\section{Terms of Use}

This article was downloaded from Harvard University's DASH repository, and is made available under the terms and conditions applicable to Other Posted Material, as set forth at http:// nrs.harvard.edu/urn-3:HUL.InstRepos:dash.current.terms-of-use\#LAA

\section{Share Your Story}

The Harvard community has made this article openly available.

Please share how this access benefits you. Submit a story.

\section{Accessibility}


Oxford Review of Economic Policy, Volume 27, Number 4, 2011, pp. 536-562

\title{
Over-optimism in forecasts by official budget agencies and its implications
}

\author{
Jeffrey Frankel*
}

\begin{abstract}
The paper studies forecasts of real growth rates and budget balances made by official government agencies among 33 countries. In general, the forecasts are found: (i) to have a positive average bias, (ii) to be more biased in booms, and (iii) to be even more biased at the 3-year horizon than at shorter horizons. This over-optimism in official forecasts can help explain excessive budget deficits, especially the failure to run surpluses during periods of high output: if a boom is forecasted to last indefinitely, retrenchment is treated as unnecessary. Many believe that better fiscal policy can be obtained by means of rules such as ceilings for the deficit or, better yet, the structural deficit. But we also find: (iv) countries subject to a budget rule, in the form of euroland's Stability and Growth Pact (SGP), make official forecasts of growth and budget deficits that are even more biased and more correlated with booms than do other countries. This effect may help explain frequent violations of the SGP. The question becomes how to overcome governments' tendency to satisfy fiscal targets by wishful thinking rather than by action. Chile in 2000 created structural budget institutions that may have solved the problem. Independent expert panels, insulated from political pressures, are responsible for estimating the long-run trends that determine whether a given deficit is deemed structural or cyclical. The result is that Chile's official forecasts of growth and the budget have not been overly optimistic, even in booms. Unlike many countries in the North, Chile took advantage of the 2002-7 expansion to run budget surpluses, and so was able to ease in the 2008-9 recession.
\end{abstract}

Key words: budget rule, Chile, countercyclical, fiscal, forecast, institutions, procyclical, Stability and Growth Pact, structural budget

JEL classification: E62, H50

\section{Introduction}

Many countries are apparently unable to bring budget deficits under control though eager to do so. This used to be less true of countries in the 'North', those traditionally known as industrialized, than of those in the 'South' - that is to say, developing countries. The problem

*Harvard Kennedy School, e-mail: jeffrey_frankel@harvard.edu

The author wishes to thank Jesse Schreger for exceptional research assistance; Roel Beetsma, Carlos Alvarado, Mauricio Calani, Mauricio Cardenas, Luis Céspedes, Massimo Giuliodori, Martin Mühleisen, Claudia Bulos Ramirez, and Victoria Rodriguez for help acquiring data; Philippe Bacchetta, Roel Beetsma, Cynthia Balloch, Sebastian Bustos, Dieter Helm, Philippe Martin, Guillermo Perry, Klaus Schmidt-Hebbel, and two anonymous referees for comments; and the Weatherhead Center for International Affairs at Harvard for support.

doi: 10.1093/oxrep/grr025

(C) The Author 2012. Published by Oxford University Press.

For permissions please e-mail: journals.permissions@oup.com 
of the former has gotten worse since 2000, however - the same period during which many of the latter have escaped their past history of excessive deficits and debts, attaining smaller deficits or even surpluses.

The problem in the North is worse than just a tendency towards excessive budget deficits on average. Some advanced countries have followed generally procyclical fiscal policies since 2000: taking steps to cut tax rates and increase spending during expansion and then moving in the opposite direction in response to recession. This pattern is likely to exacerbate the swing in the business cycle. Because the United States, the United Kingdom, and most members of the eurozone failed to take advantage of the expansion of 2002-7 to attain budget surpluses, after global recession hit in 2008-9 they found themselves with such high levels of debt that they felt constrained to tighten fiscal policy. Meanwhile, China, Chile, Korea, and some other emerging market or commodity-producing countries had attained sufficiently strong fiscal positions by 2007 that they felt able to respond to the recession with substantial easing; this helps explain why they experienced a shorter and less severe downturn.

There is a huge public choice literature offering political economy explanations for excessive growth of government spending and budget deficits. Budget deficits are often viewed as the product of politicians who have short horizons. Short horizons can in turn be rational under a system where politicians' terms in office are typically short and their priorities for what they would like to spend money on differ from those of their opponents. ${ }^{1}$ Dispersed political power has not only been associated with fiscal policies that are excessively expansionary on average but also with those that are excessively procyclical. ${ }^{2}$ Other explanations for budget deficits abound as well. ${ }^{3}$

Of the various ways that governments can fail to save enough, especially in boom times, this paper studies the possibility that official forecasts of revenue are overly optimistic. If the official forecast is optimistic, there is no reason to take painful steps such as cutting spending or raising taxes. A prominent example is the overly optimistic US budget forecasts made by the White House in 2001 and subsequent years. Its unrealistic forecasts were plausibly a major reason for the failure of the United States to take advantage of the opportunity to save during the 2002-7 expansion. ${ }^{4}$ European governments, too, persistently explained away large deficits during this period with unrealistic predictions that in the coming years the deficits would fall.

Are such instances of over-optimism in official forecasts systematic enough to be statistically significant? Is the forecasting bias worse during periods of expansion? What is the role of budget rules, such as the Stability and Growth Pact (SGP)? How can the problem of excessive exuberance on the part of fiscal authorities during booms be addressed? This paper explores the bias towards over-optimism in official forecasts of GDP and budget balances among 33 countries. The bias probably contributes to excessive deficits. A common

\footnotetext{
${ }^{1}$ For example, Alesina and Tabellini (1990a,b) and Grilli et al. (1991). Roubini and Sachs (1989a,b) argue that the problem may especially result from difficulties that multi-party coalition governments have in forming consensus.

${ }^{2}$ Lane (2003). Countries with volatile output are also prone to procyclical fiscal policy.

${ }^{3}$ Surveys include Alesina et al. (1998) and Persson and Tabellini (2002).

${ }^{4}$ The White House claim in 2001 that budget surpluses over the subsequent 10 years would total nearly $\$ 5$ trillion, in round numbers, was a major factor in the political ability of the new administration to persuade the Congress to approve long-term tax cuts and spending increases. The outcome was that the 10-year US fiscal outlook soon swung to a cumulative $\$ 5$ trillion deficit. One component of the over-optimism was a belief that tax cuts would stimulate economic growth so much they would raise tax revenue rather than lowering it (Frankel, 2003, 2008b).
} 
prescription for excessive deficits is a budget rule. But we find that a rule such as the SGP only worsens the bias towards over-optimism in official forecasts: political leaders meet their targets by adjusting their forecasts rather than by adjusting their policies. The paper finds a possible solution in Chile's structural budget institutions, particularly its insulation of official forecasts from political temptation.

\section{Are official budget forecasts overly optimistic on average?}

There is already evidence that government budget forecasts in many countries are overly optimistic on average, often because official estimates of economic growth are overly optimistic.

Studies of growth forecasts by US government agencies in the 1960s and 1970s used to find them generally unbiased and as accurate as private-sector forecasts. But subsequent analyses found bias. McNees (1995) updated the time sample to 1994 and found an optimistic bias in some official forecasts of long-term growth. Auerbach (1994) found overly optimistic forecasts in the decade preceding 1993. Auerbach (1999) again found a tendency for the US Office of Management and Budget (OMB), in its semi-annual forecast, to overestimate revenues during the period 1986-93, but found a tendency to underestimate revenues during the period 1993-9. McNab et al. (2007) find that OMB's 1-year ahead forecasts of US tax receipts were biased over the period 1963-2003. They suggest that the bias may be strategic on the part of various administrations seeking to achieve particular goals, such as overstating budget balance when the administration is seeking to increase spending or cut taxes. Frendreis and Tatalovich (2000) find that US administrations (OMB) are less accurate in estimating growth, inflation, and unemployment than are the independent Congressional Budget Office and Federal Reserve Board. They find partisan bias, which they interpret as Republican administrations over-forecasting inflation and Democratic administrations over-forecasting unemployment.

Forni and Momigliano (2004) find optimism bias among OECD countries more generally. Ashiya (2007) finds that official Japanese growth forecasts at a 16-month horizon are biased upwards by 0.7 percentage points, and significantly less accurate than private-sector forecasts. Canada evidently underestimated its budget deficits in the late 1980s and early 1990s, but subsequently (1994-2004) overestimated them, perhaps to reduce the risk of missing its target of a balanced budget under its strengthened institutional framework (O’Neill, 2005; Mühleisen et al., 2005).

Jonung and Larch (2006) find a clear tendency for EU governments, when making budget plans, to overestimate the economic growth rate. The tendency towards overly optimistic forecasts is notably strong in Italy (the average bias is around 0.6 percentage points per year) and Germany. The UK is the exception. A three-author team finds a statistically significant optimism bias for some euro members: France, Italy, and Portugal over the period 19912002 (Strauch et al., 2004); and Germany, Italy, Greece, Luxemburg, and Portugal when the data set is updated to 2004 (Von Hagen et al., 2009). The UK, Finland, and Sweden, on the other hand, tend to overestimate their deficits. In light of this difference, it is suggestive that the UK and Sweden were not trying to get into the euro, which was supposed to require meeting the fiscal criteria of the 1992 Maastricht Treaty, while the others were trying to get 
in, and are now there and thus subject to the SGP. ${ }^{5}$ Brück and Stephan (2006) explicitly conclude that eurozone governments have manipulated deficit forecasts before elections since the introduction of the SGP. Most of these authors argue that the systematic overoptimism in ex ante forecasts translates directly into larger ex post deficits, and particularly to deficits larger than targeted under the SGP.

Similarly, Beetsma et al. (2009) find that ex post budget balances among SGP countries systematically fall short of official ex ante plans. Marinheiro (2010) adds another complete business cycle to the data under the SGP, and again finds that the forecasts of European fiscal authorities are overly optimistic on average. This evidence is not consistently strong across the set of 15 EU countries, but the bias is high for France, Italy, and Portugal at all forecast horizons. ${ }^{6}$ Beetsma and Giuliodori (2010) and Beetsma et al. (2011) decompose the overall optimism bias in the budget forecasts of EU governments into the component that arises between initial plans and the first release of actual budget numbers, and the component that arises between the first release and the final revised budget numbers.

There is far less research into the forecasting records of fiscal authorities in low-income or medium-income countries than in advanced countries. One reason is limited availability of data. But some major emerging market countries became more transparent about their budgets after the crises of the 1990s.

We were able to obtain government forecasts of the budget balance for 33 countries. A majority of the countries are European (26, of whom 17 are euro members, counting Estonia, which was approved for membership in 2010). The heavy representation of these countries in the sample is because, unlike most countries, they report official budget forecast data - as a side-effect of the SGP itself. But the European data will allow us, below, to test for the effect on forecast bias of the political pressure from a budget rule such as the SGP. Of the additional seven countries, three are advanced commodity-exporting countries (Australia, Canada, and New Zealand), three are middle-sized emerging market countries that also export commodities (Chile, Mexico, and South Africa), and the last is the United States. Emerging markets are under-represented; but national sources must be consulted one by one, and for most countries the answer is that such data are not available, and perhaps do not exist in cumulative form even inside the government.

Appendix Table 1 reports the mean errors country by country. The fourth column reports the official ex ante forecast minus actual ex post outcome 1 year ahead: mean forecast error, minimum, and maximum. Some countries report forecasts 2 or 3 years ahead; these forecast errors are shown in the fifth and sixth columns, respectively. The general pattern, as suspected, is over-optimism. In most cases, the positive bias emerges more strongly at the 3-year horizon than the 2-year horizon, and more at the 2-year horizon than the 1-year horizon. The average across all countries is an upward bias of 0.2 per cent of GDP at the 1 -year horizon, 0.8 per cent 2 years ahead, and a hefty 1.5 per cent 3 years ahead. It is no surprise that the absolute magnitude of forecast errors increases with the length of the horizon; this would be true even if forecasts were optimal. But the term structure of the bias suggests that the longer the horizon and the greater the genuine uncertainty, the more the scope for wishful thinking.

\footnotetext{
${ }^{5}$ Indeed, Sweden's strategy for staying out may have been to feign fiscal imprudence!

${ }^{6} \mathrm{He}$ proposes delegating the macroeconomic forecasting to supranational authorities, such as the EU Commission or the International Monetary Fund.
} 
If bias in forecasts is a reason for excessive deficits in booms, one would expect the problem to be worse in developing countries. Many authors have documented that fiscal policy has tended to be procyclical in developing and commodity-exporting countries, in comparison with industrialized countries. ${ }^{7}$ Most studies look at the procyclicality of government spending, because tax receipts are particularly endogenous with respect to the business cycle. An important reason for procyclical spending is precisely that government receipts from taxes or royalties rise in booms, and the government cannot resist the temptation or political pressure to increase spending proportionately, or more than proportionately. Procyclicality has historically been especially pronounced in countries that possess natural resources and where income from those resources tends to dominate the business cycle. ${ }^{8}$

Interestingly, the bias in our sample of 33 countries is not greater for commodity producers or developing countries than it is for others, even though such countries have been observed to have more highly procyclical fiscal policies historically than advanced countries. The US and UK forecasts have substantial positive biases around 3 per cent of GDP at the 3-year horizon (approximately equal to their actual deficit on average; in other words, on average they repeatedly forecast a disappearance of their deficits that never came). The forecast biases in the euro countries have already been noted from the literature. But official budget forecasts in South Africa were overly pessimistic on average, as were those for Canada and New Zealand. Mexico is just slightly overoptimistic on average. Chile had no optimism bias; the conclusion of this paper will be that this achievement was the result of admirable budget institutions that insulate the forecasting process from political pressure. ${ }^{9}$

\section{Are official growth forecasts overly optimistic on average?}

One likely reason for upward bias in official budget forecasts, in advanced and developing countries alike, is upward bias in economic assumptions, such as economic growth and commodity prices. This hypothesis is of central interest in the paper. But we should note that there are other possible reasons as well why official budget forecasts could be overly optimistic on average. The official forecast may represent the desired target in the plan of the executive, but there could be slippage by the time the final expenditures are made, owing to the usual political pressures. ${ }^{10}$ Those who write the initial budget plan may even be fully aware of this tendency towards slippage and may place a lower priority on statistically unbiased forecasts than on setting an ambitious goal so as to achieve as strong a final outcome as possible.

${ }^{7}$ Gavin and Perotti (1997), Tornell and Lane (1999), Calderón and Schmidt-Hebbel (2003), Kaminsky et al. (2005), Talvi and Végh (2005), Mendoza and Oviedo (2006), Alesina et al. (2008), and Ilzetski and Vegh (2008).

${ }^{8}$ Gelb (1986), Cuddington (1989), Medas and Zakharova (2009), Arezki and Brückner (2010), and Arezki and Ismail (2010).

${ }^{9}$ I explore Chile's achievement of countercyclical fiscal policy and the role of official forecasts in greater detail elsewhere: Frankel (2011).

${ }^{10}$ Cárdenas et al. (2009) show how this process works for Colombia. There may also be slippage that is not captured in the final budget numbers, because it takes place in 'off budget' agencies or categories. 
Appendix Table 2 reports the mean errors made by government forecasts of the rate of growth of GDP, for our 33 countries. Again the overall pattern is an upward bias on average, which rises with the length of the horizon: 0.4 per cent when looking 1 year ahead; 1.1 per cent at the 2-year horizon; and 1.8 per cent at 3 years. Again, the bias appears in the US and many other advanced countries, and not necessarily among the commodity producers in this sample. ${ }^{11}$ Chile on average under-forecast its growth rate, by 0.8 per cent at the 1 -year horizon. South Africa was just slightly too optimistic on average $(0.2$ per cent at the 1 -year horizon), and Mexico more so (1.7 per cent).

Of more central interest for this paper are cyclical patterns in forecast errors. Perhaps the problem is that government officials tend to get carried away during expansions, unrealistically extrapolating them indefinitely into the future? Fewer authors have looked for cyclical patterns in the systematic forecast errors made by national authorities than unconditional average errors. One possible exception: an implication of Marinheiro (2008) seems to be that European policy-makers have underestimated growth after the trough of the business cycle. ${ }^{12}$

\section{The influence of macroeconomic fluctuations on budget balances}

Before we attempt to detect systematic cyclical patterns in the errors made in official forecast of budget deficits, it would be useful to confirm that a few macroeconomic variables, such as the real growth rate, are in fact key to the ex post determination of the actual budget balance. Then we will know to look to over-optimism in forecasts of these macroeconomic variables as a possible source of observed over-optimism in budget forecasts.

In Table 1(a) we regress the ex post budget outcome (expressed relative to the ex ante attempt to predict it) against the ex post real growth rate (again expressed relative to the forecast), for our full set of countries. At all three horizons, the growth rate is highly significant at determining the budget balance. For every 1 per cent of growth, relative to what was forecast a year previously, the budget improves by about half that amount, relative to what was forecast a year previously. The same is true at the 2-year and 3-year horizons. Thus we are likely to find over-optimism in forecasting the budget where we find over-optimism in predicting real growth.

In some countries, inflation pushes taxpayers into a higher tax bracket. ${ }^{13}$ Accordingly, in Table 1(b) we add the inflation rate as another possible determinant of the budget balance. (Both are again expressed relative to the official ex ante forecasts.) The finding is that

\footnotetext{
${ }^{11}$ The commodity exporters in this data set almost certainly represent some sample selection bias, in that only governments that are transparent enough to publish their budget forecasts are included, for obvious reasons. Thus we do not emphasize tests of whether official forecasts behave differently for commodity exporters than for others. Such tests appear to show that the special commodity exporters in our sample are actually less optimistic than others (Frankel, 2011, Appendix Table 3).

12 The time period is 1999-2006. He is motivated by the finding of Galí and Perotti (2003) that discretionary fiscal policy became more countercyclical among euro countries after the Maastricht Treaty, and attributes it to cyclically systematic forecast errors rather than to ex ante intentions on the part of fiscal authorities, which were actually procyclical.

${ }^{13}$ At high levels of inflation, the Tanzi effect can go the other direction: owing to lags in tax collection, inflation erodes the real value of tax receipts and can worsen the budget deficit.
} 
Table 1(a): GDP as a determinant of budget balance as a \% of GDP

\begin{tabular}{lccc}
\hline Variables & $\mathbf{1}$ year ahead & 2 years ahead & 3 years ahead \\
\hline GDP forecast error & $0.479^{\star \star \star}$ & $0.525^{\star \star \star}$ & $0.489^{\star \star \star}$ \\
& $(0.060)$ & $(0.068)$ & $(0.076)$ \\
Constant & 0.155 & 0.198 & $0.556^{\star}$ \\
& $(0.174)$ & $(0.249)$ & $(0.314)$ \\
Observations & 367 & 277 & 175 \\
Countries & 33 & 31 & 28 \\
R $^{2}$ & 0.280 & 0.369 & 0.322 \\
RMSE & 1.695 & 2.053 & 2.327 \\
\hline
\end{tabular}

Notes: ${ }^{* *} p<0.01,{ }^{* *} p<0.05,{ }^{*} p<0.1$. Robust standard errors in parentheses. Estimated with random effects by country.

Table 1(b): GDP and inflation as determinants of budget balance as a \% of GDP

\begin{tabular}{lccc}
\hline Variables & 1 year ahead & 2 years ahead & 3 years ahead \\
\hline GDP forecast error & $0.498^{* * *}$ & $0.466^{* * *}$ & $0.460^{\star * *}$ \\
& $(0.055)$ & $(0.064)$ & $(0.074)$ \\
Inflation forecast error & 0.158 & $0.196^{*}$ & $0.254^{* *}$ \\
& $(0.109)$ & $(0.116)$ & $(0.092)$ \\
Constant & 0.331 & $0.593^{*}$ & $0.913^{* *}$ \\
& $(0.212)$ & $(0.306)$ & $(0.356)$ \\
Observations & 214 & 185 & 159 \\
Countries & 28 & 27 & 27 \\
$\mathrm{R}^{2}$ & 0.351 & 0.402 & 0.351 \\
RMSE & 1.634 & 2.127 & 2.313 \\
\hline
\end{tabular}

Notes: ${ }^{* *} p<0.01,{ }^{* *} p<0.05,{ }^{*} p<0.1$. Robust standard errors in parentheses. Random effects by country. All variables are lagged so that they line up with the year in which the forecast was made, not the year being forecast.

inflation does indeed translate into a strong budget surplus, to a statistically significant degree at the 2- and 3-year horizons. ${ }^{14}$

\section{Are budget forecasts more prone to over-optimism in booms?}

We now return to examination of the cyclical pattern of bias in government forecasts. Table 2 goes beyond testing for unconditional over-optimism in official budget forecasts, to see if the bias is greater in a boom, here measured as the deviation of output from a quadratic trend. The cyclical term is, indeed, positive and highly significant: over-optimism tends to be greater in booms. Its estimated magnitude rises as we move from the 1-year horizon to the 2-year horizon, and again as we move to the 3 -year horizon. This makes sense: there is more scope

\footnotetext{
${ }^{14}$ These tables allow random effects by country (which facilitates comparison across the three columns even though the sample of countries diminishes). Results without random effects are reported in the January 2011 working paper (Frankel, 2011). There the effect of inflation appeared a bit stronger statistically.
} 
Table 2: Budget balance forecast error as \% of GDP, full dataset

\begin{tabular}{lccc}
\hline Variables & 1 year ahead & 2 years ahead & 3 years ahead \\
\hline GDPdevq & $0.093^{* * *}$ & $0.258^{* * *}$ & $0.289^{* * *}$ \\
& $(0.019)$ & $(0.040)$ & $(0.063)$ \\
Constant & 0.201 & $0.649^{* * *}$ & $1.364^{* * *}$ \\
& $(0.197)$ & $(0.231)$ & $(0.348)$ \\
Observations & 398 & 300 & 179 \\
R $^{2}$ & 0.033 & 0.113 & 0.092 \\
RMSE & 2.248 & 2.732 & 3.095
\end{tabular}

Notes: Variable is lagged so that it lines up with the year in which the forecast was made and not the year being forecast. ${ }^{* \star} p<0.01,{ }^{* \star} p<0.05,{ }^{*} p<0.1$. Robust standard errors in parentheses, clustered by country.

for wishful thinking at longer horizons because the uncertainty is genuinely higher. But there is also evidence of a bias towards optimism even when GDP is at its trend value: the constant term is positive, and statistically significant at the 2- and 3-year horizons.

We have four important findings so far and they are visible in Figures $1(a-c)$. First, budget forecasts in most countries are biased upwards (most points appear above the zero level of budget prediction error). Second, Chile is an exception (the Xs in Figure 1(a) mostly lie below the zero level). Third, the bias is greater at longer horizons (compare the figures with each other). And fourth, the bias is greater in booms (a regression line slopes upwards). ${ }^{15}$

\section{Budget rules}

A common prescription to fix budget deficits that are too high on average and too procyclical is by means of institutions that constrain fallible politicians, such as formal rules to constrain fiscal policy. ${ }^{16}$ Examples of such rules are the budget deficit ceilings that supposedly constrain members of euroland (3 per cent of GDP under the SGP) or US proposals for a 'balanced budget amendment' (zero deficit). But those attempts have failed, in part because they are too rigid to allow the need for deficits in recessions, counterbalanced by surpluses in good times.

It is not always the case that 'tougher' constraints on fiscal policy increase effective budget discipline. Countries often violate their constraints. In an extreme set-up, a rule that is too rigid - so rigid that official claims that it will be sustained are not credible - might even lead to looser fiscal outcomes than if a more moderate and flexible rule had been specified at the outset (Neut and Velasco, 2003). Certainly euro countries large and small have repeatedly violated the fiscal rules of the SGP, originally a simple ceiling on the budget deficit of 3 per

\footnotetext{
15 The country with the longest sample period in Figure 1(a) is Chile (1977-2009). In Figure 1(b) the United States has the longest sample period (1987-2009). In Figure 1(c) numerous European countries have a sample period of 2001-9. For the individual country sample periods, see Appendix Table 1.

16 Those who emphasize the role of institutions or rules in delivering more responsible fiscal policy include Buchanan (1967), von Hagen and Harden (1995), Alesina and Perotti (1995, 1996), Poterba (1997), Poterba and von Hagen (1999), Persson and Tabellini (2004), Wyplosz (2005), Calderón and Schmidt-Hebbel (2008), and Calderón et al. (2010). For commodity exporters and developing countries more specifically: Alesina et al. (1999), Stein et al. (1999), Davis et al. (2001, 2003), and Ossowski et al. (2008), among others.
} 
Figure 1(a): Chile's budget forecasts are not prone to the optimism bias of others

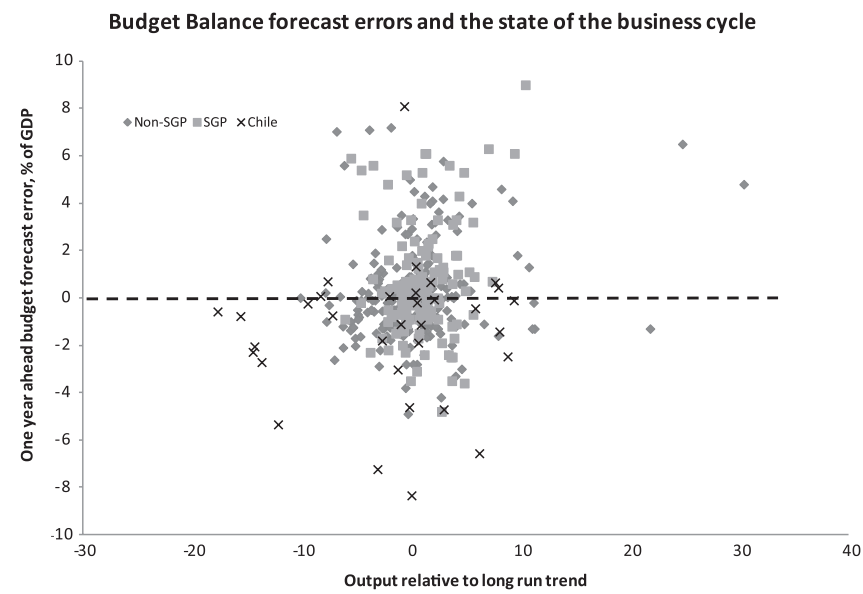

Figure 1(b): The bias is greater at longer horizons than at the 1-year horizon

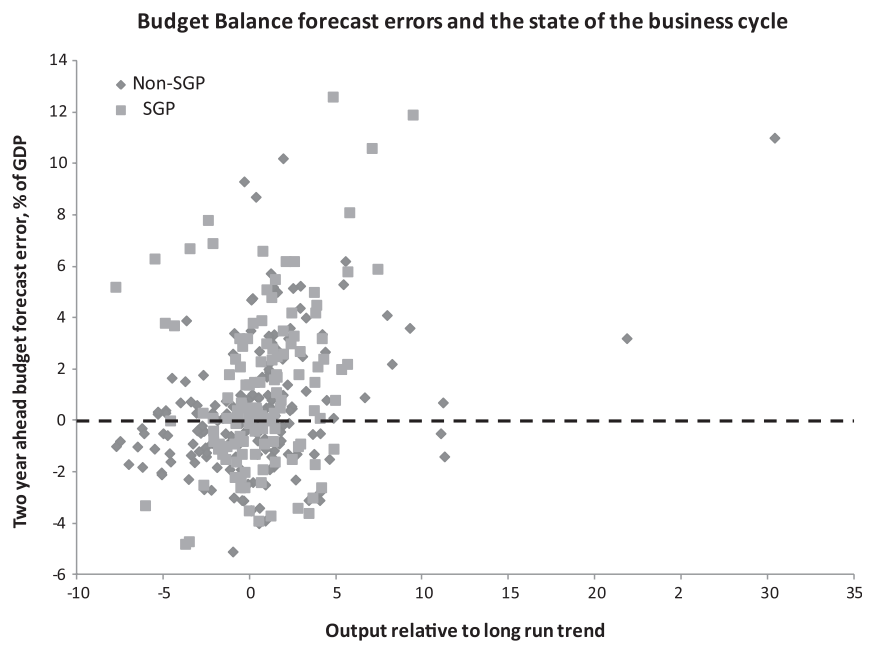

cent of GDP. The main idea that Brussels has had for enforcement of the SGP is that a government that was unable to reduce its budget deficit to the target would have to pay a substantial fine, which of course would add to the budget deficit - an enforcement mechanism that seems unlikely to help the credibility of the rule. ${ }^{17}$

${ }^{17}$ An analogous example outside the realm of macroeconomic policy is the idea that the Kyoto Protocol on Global Climate Change would be enforced by a provision requiring countries that exceeded their allocation of greenhouse-gas emissions in one period to cut emissions even further below target in the subsequent period, a penalty with interest. One might as well tell someone in a diet plan that if they fail to lose 5 pounds in the first week, then they have to lose 10 pounds in the second week. 
Figure 1(c): The bias is greater in booms

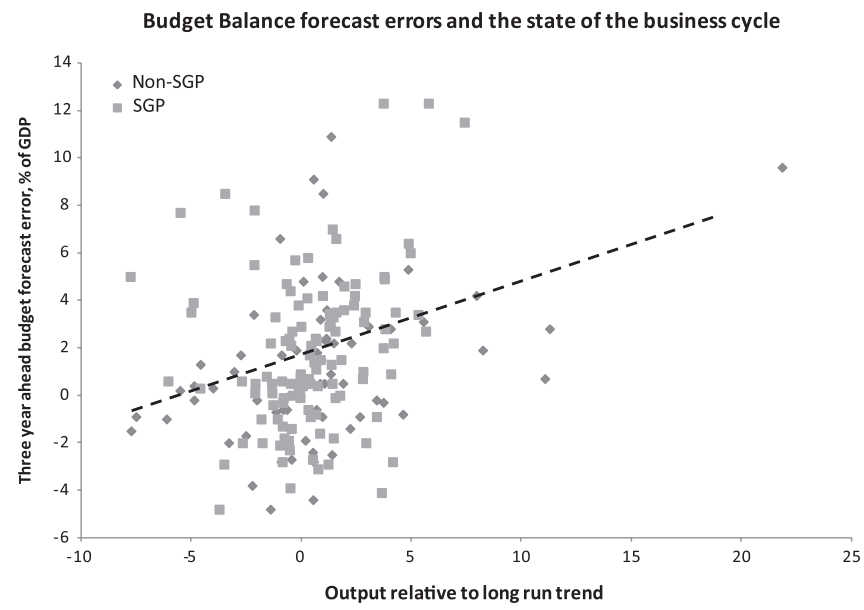

Credibility can be a problem for budget institutions either with or without uncertainty regarding the future path of the economy. Consider first the non-stochastic case. Even in cases where the future proceeds as expected when the rule was formulated, the target may be up against predictably irresistible political pressures. 'Special fiscal institutions', which include fiscal rules and fiscal responsibility legislation, are often abandoned before long. ${ }^{18}$

The case of rules that are too onerous to last arises particularly in the stochastic context. A target that might have been a reasonable goal ex ante, such as an unconditionally balanced budget, becomes unreasonable after an unexpected shock, such as a severe fall in export prices or national output. Common examples are rigid balanced budget rules that do not allow the possibility of fiscal deficits in bad times. A sensible alternative is to specify rules that mandate changes in response to changed circumstances. Instead of targeting an actual budget balance of zero, or some other numerical surplus, the rule can target a number for the structural or cyclically adjusted budget.

This alternative may not work, however, if the political process determines whether a particular deficit is judged structural or not. Politicians can always attribute a budget deficit to unexpectedly and temporarily poor economic growth. Since there is no way of proving what an unbiased forecast of growth is, there is no way of disproving the politicians' claim that the shortfall is not their responsibility. Thus the rule does not necessarily succeed in imposing discipline.

\section{Are official budget forecasts more prone to over-optimism when the deficit is subject to a rule?}

An interesting question is whether a legal agreement to target a particular budget balance can result in official budget forecasts that have a tendency to be more overly optimistic than they would otherwise be. Beetsma et al. (2009) use the phrase 'planning to cheat' to describe

\footnotetext{
${ }^{18}$ An econometric analysis of these Special Financial Institutions for oil-producers by Ossowski et al. (2008, pp. $19,23,24,38-43$ ) finds no statistically significant effect on the actual fiscal stance. This may be partly due to econometric limitations. But it is evidently also in part due to governments that, after having adopted these institutions, subsequently find them too rigid in practice and so weaken or abandon them.
} 
biased forecasts in rule-bound countries. If formal constraints on the budget deficit, by themselves, are likely to lead to bias in official budget forecasts, they might in theory even thereby lead to less budget discipline than in a country without rules. The question of whether rules impair forecasting is distinct, however, from the question of whether rules help deliver fiscal discipline. ${ }^{19}$

It is highly suggestive that Italy and other Mediterranean countries, the EU countries that had to work the hardest to meet the Maastricht fiscal criteria, are also the ones found by several studies to have had the greatest bias in their forecasts. Recall that in the estimates of Jonung and Larch (2006), the UK is the country that does not show significant overoptimism. Since the UK has not sought entrance into the euro, their finding is consistent with the possibility that the bias is euro-related. Beetsma et al. (2010) find that in the Netherlands, forecasts of growth rates (by the Economics Agency) and revenue (by the Finance Ministry) have been realistic, unlike over-optimistic projections in other EU countries. They attribute the recent record in part to a new regime of 'trend-based budget policy'. Thus the literature is consistent with the hypothesis that formal adoption of a budget deficit ceiling may, by itself, induce a tendency towards over-optimism in official forecasts, but that over-optimism can be counteracted by the right sort of fiscal regime or institution.

We report our own tests of the 'planning to cheat' hypothesis, on a bigger data set than the earlier studies. The examples of rule-bound countries are the euro members, as in the literature. But rather than comparing them only to other European countries, we also include others, including a number of commodity producers.

Table 3(a): Budget balance forecast error as \% of GDP, European countries

\begin{tabular}{|c|c|c|c|c|c|c|}
\hline Variables & $\begin{array}{l}1 \text { year } \\
\text { ahead }\end{array}$ & $\begin{array}{l}2 \text { years } \\
\text { ahead }\end{array}$ & $\begin{array}{l}3 \text { years } \\
\text { ahead }\end{array}$ & $\begin{array}{l}1 \text { year } \\
\text { ahead }\end{array}$ & $\begin{array}{l}2 \text { years } \\
\text { ahead }\end{array}$ & $\begin{array}{l}3 \text { years } \\
\text { ahead }\end{array}$ \\
\hline SGPdummy & $\begin{array}{c}0.136 \\
(0.342)\end{array}$ & $\begin{array}{c}0.609^{*} \\
(0.330)\end{array}$ & $\begin{array}{c}0.372 \\
(0.346)\end{array}$ & $\begin{array}{c}-0.0842 \\
(0.333)\end{array}$ & $\begin{array}{c}0.0204 \\
(0.360)\end{array}$ & $\begin{array}{c}-0.183 \\
(0.391)\end{array}$ \\
\hline SGP*GDPdevq & & & & $\begin{array}{c}0.164^{\star *} \\
(0.066)\end{array}$ & $\begin{array}{l}0.505^{\star * *} \\
(0.135)\end{array}$ & $\begin{array}{l}0.545^{\star * *} \\
(0.146)\end{array}$ \\
\hline Constant & $\begin{array}{c}0.566^{* *} \\
(0.223)\end{array}$ & $\begin{array}{l}0.855^{\star \star \star} \\
(0.289)\end{array}$ & $\begin{array}{l}1.493^{\star * *} \\
(0.359)\end{array}$ & $\begin{array}{c}0.558^{\star \star *} \\
(0.210)\end{array}$ & $\begin{array}{l}0.820^{\star \star \star} \\
(0.292)\end{array}$ & $\begin{array}{l}1.491^{\text {*** }} \\
(0.360)\end{array}$ \\
\hline Observations & 255 & 221 & 164 & 254 & 221 & 164 \\
\hline Countries & 26 & 26 & 25 & 26 & 26 & 25 \\
\hline $\mathrm{R}^{2}$ & 0.001 & 0.006 & 0.002 & 0.021 & 0.076 & 0.076 \\
\hline RMSE & 2.162 & 2.937 & 3.145 & 2.178 & 2.827 & 3.024 \\
\hline
\end{tabular}

Notes: ${ }^{* *} p<0.01,{ }^{* *} p<0.05,{ }^{*} p<0.1$. Robust standard errors in parentheses. Estimated with random effects by country. European countries: Austria, Belgium, Cyprus, Czech Republic, Denmark, Estonia, Finland, France, Germany, Greece, Hungary, Ireland, Italy, Latvia, Lithuania, Luxemburg, Malta, Netherlands, Poland, Portugal, Slovakia, Slovenia, Spain, Sweden, Switzerland, and United Kingdom.

\footnotetext{
${ }^{19}$ For example, if we find a tendency towards overoptimistic forecasts, it could be only a partial offset to tighter fiscal discipline. Or we may find that forecasts are not overly optimistic at all, and yet budget deficits could turn out to violate legal constraints nonetheless.
} 
Table 3(b): Budget balance forecast error as \% of GDP, western European countries

\begin{tabular}{|c|c|c|c|c|c|c|}
\hline Variables & $\begin{array}{l}1 \text { year } \\
\text { ahead }\end{array}$ & $\begin{array}{l}2 \text { years } \\
\text { ahead }\end{array}$ & $\begin{array}{c}3 \text { years } \\
\text { ahead }\end{array}$ & $\begin{array}{l}1 \text { year } \\
\text { ahead }\end{array}$ & $\begin{array}{c}2 \text { years } \\
\text { ahead }\end{array}$ & $\begin{array}{l}3 \text { years } \\
\text { ahead }\end{array}$ \\
\hline SGPdummy & $\begin{array}{c}-0.058 \\
(0.331)\end{array}$ & $\begin{array}{l}0.886^{* *} \\
(0.373)\end{array}$ & $\begin{array}{l}1.008^{* * *} \\
(0.343)\end{array}$ & $\begin{array}{c}-0.205 \\
(0.333)\end{array}$ & $\begin{array}{c}0.351 \\
(0.322)\end{array}$ & $\begin{array}{c}0.454 \\
(0.347)\end{array}$ \\
\hline SGP*GDPdevq & & & & $\begin{array}{c}0.147^{* *} \\
(0.065)\end{array}$ & $\begin{array}{l}0.511^{* * *} \\
(0.162)\end{array}$ & $\begin{array}{l}0.536^{\text {*** }} \\
(0.173)\end{array}$ \\
\hline Constant & $\begin{array}{c}0.642^{* *} \\
(0.321)\end{array}$ & $\begin{array}{c}0.529 \\
(0.476)\end{array}$ & $\begin{array}{c}0.939 \\
(0.605)\end{array}$ & $\begin{array}{c}0.608^{\star *} \\
(0.301)\end{array}$ & $\begin{array}{c}0.432 \\
(0.487)\end{array}$ & $\begin{array}{c}0.937 \\
(0.613)\end{array}$ \\
\hline Observations & 205 & 181 & 134 & 205 & 181 & 134 \\
\hline Countries & 16 & 16 & 15 & 16 & 16 & 15 \\
\hline $\mathrm{R}^{2}$ & 0.000 & 0.011 & 0.008 & 0.027 & 0.010 & 0.096 \\
\hline RMSE & 2.012 & 2.745 & 2.954 & 2.013 & 2.604 & 2.818 \\
\hline
\end{tabular}

Notes: ${ }^{* *} p<0.01,{ }^{* *} p<0.05,{ }^{*} p<0.1$. Robust standard errors in parentheses. random effects.

Western European countries are Austria, Belgium, Denmark, Finland, France, Germany, Greece, Ireland, Italy, Luxemburg, Netherlands, Portugal, Spain, Sweden, Switzerland, and United Kingdom.

Table 3(c): Budget balance forecast error as a \% of GDP, full dataset

\begin{tabular}{|c|c|c|c|c|c|c|}
\hline Variables & $\begin{array}{l}1 \text { year } \\
\text { ahead }\end{array}$ & $\begin{array}{l}2 \text { years } \\
\text { ahead }\end{array}$ & $\begin{array}{c}3 \text { years } \\
\text { ahead }\end{array}$ & $\begin{array}{l}1 \text { year } \\
\text { ahead }\end{array}$ & $\begin{array}{l}2 \text { years } \\
\text { ahead }\end{array}$ & $\begin{array}{c}3 \text { years } \\
\text { ahead }\end{array}$ \\
\hline SGPdummy & $\begin{array}{c}0.368 \\
(0.342)\end{array}$ & $\begin{array}{l}0.922^{* * *} \\
(0.329)\end{array}$ & $\begin{array}{c}0.625 \\
(0.415)\end{array}$ & $\begin{array}{c}0.182 \\
(0.335)\end{array}$ & $\begin{array}{c}0.331 \\
(0.355)\end{array}$ & $\begin{array}{c}0.0663 \\
(0.449)\end{array}$ \\
\hline $\mathrm{SGP}^{*} \mathrm{GDP} d e v q$ & & & & $\begin{array}{c}0.161^{\text {** }} \\
(0.065)\end{array}$ & $\begin{array}{l}0.509^{\star \star \star *} \\
(0.147)\end{array}$ & $\begin{array}{l}0.544^{* * *} \\
(0.148)\end{array}$ \\
\hline Constant & $\begin{array}{c}0.245 \\
(0.198)\end{array}$ & $\begin{array}{l}0.530^{* *} \\
(0.268)\end{array}$ & $\begin{array}{l}1.235^{\star * *} \\
(0.408)\end{array}$ & $\begin{array}{c}0.219 \\
(0.193)\end{array}$ & $\begin{array}{c}0.501^{*} \\
(0.268)\end{array}$ & $\begin{array}{l}1.240^{* * *} \\
(0.404)\end{array}$ \\
\hline Observations & 399 & 300 & 179 & 398 & 300 & 179 \\
\hline Countries & 33 & 31 & 29 & 33 & 31 & 29 \\
\hline $\mathrm{R}^{2}$ & 0.018 & 0.023 & 0.008 & 0.029 & 0.080 & 0.076 \\
\hline RMSE & 2.113 & 2.701 & 3.130 & 2.122 & 2.614 & 3.011 \\
\hline
\end{tabular}

Notes: ${ }^{* *} p<0.01,{ }^{* *} p<0.05,{ }^{*} p<0.1$. Robust standard errors in parentheses. random effects. SGP $\equiv$ dummy for countries subject to the SGP. GDP devq $\equiv$ GDP as deviation from trend.

\section{Is over-optimism in growth forecasts worse in booms?}

We saw above that for most countries, the evolution of the actual budget deficit at a 1-year horizon is heavily influenced by the evolution of the economy, particularly GDP. In this section we test if the cyclical component to errors in budget forecasting derives to some extent from an analogous cyclical component to errors in economic forecasting. Table 4 tests if growth forecasts tend to be more overoptimistic when the economy is at a cyclical peak, here measured as the deviation of GDP from a quadratic trend. The answer is a resounding yes, especially as the horizon of the forecast lengthens, just as we found with forecasts of the budget deficit.

The next step, in Tables $5(a-c)$, is to see if the pattern is worse among rule-bound countries. In every case, the term that interacts the SGP dummy with GDP has a significantly positive effect on the error made in forecasting output, very much like the positive effect in forecasting the budget. In other words, when the economy is at a cyclical high in rule-bound countries, forecasters tend to extrapolate, as if the boom would last forever. The significant 
Table 4: GDP growth rate forecast error

\begin{tabular}{|c|c|c|c|}
\hline Variables & 1 year ahead & 2 years ahead & 3 years ahead \\
\hline \multirow[t]{2}{*}{ GDPdevq } & $0.204^{\star * *}$ & $0.497^{* * *}$ & $0.668^{* \star \star}$ \\
\hline & $(0.033)$ & $(0.078)$ & $(0.159)$ \\
\hline \multirow[t]{2}{*}{ Constant } & $0.265^{\star * *}$ & $0.799^{* * *}$ & $1.600^{* * *}$ \\
\hline & $(0.091)$ & $(0.130)$ & $(0.247)$ \\
\hline Observations & 368 & 282 & 175 \\
\hline Countries & 33 & 31 & 28 \\
\hline $\mathrm{R}^{2}$ & 0.138 & 0.298 & 0.303 \\
\hline RMSE & 2.234 & 2.945 & 3.306 \\
\hline
\end{tabular}

Notes: ${ }^{* *} p<0.01,{ }^{* *} p<0.05,{ }^{*} p<0.1$. Robust standard errors in parentheses, clustered by country. Country random effects. GDP devq $\equiv$ GDP as deviation from quadratic trend. Variable is lagged so that it lines up with the year the forecast was made in and not the year being forecast.

Table 5(a): GDP growth rate forecast error, European countries

\begin{tabular}{|c|c|c|c|c|c|c|}
\hline Variables & $\begin{array}{l}1 \text { year } \\
\text { ahead }\end{array}$ & $\begin{array}{l}2 \text { years } \\
\text { ahead }\end{array}$ & $\begin{array}{c}3 \text { years } \\
\text { ahead }\end{array}$ & $\begin{array}{l}1 \text { year } \\
\text { ahead }\end{array}$ & $\begin{array}{l}2 \text { years } \\
\text { ahead }\end{array}$ & $\begin{array}{c}3 \text { years } \\
\text { ahead }\end{array}$ \\
\hline SGPdummy & $\begin{array}{c}0.183 \\
(0.232)\end{array}$ & $\begin{array}{c}0.500 \\
(0.429)\end{array}$ & $\begin{array}{c}-0.670 \\
(0.568)\end{array}$ & $\begin{array}{c}-0.017 \\
(0.248)\end{array}$ & $\begin{array}{c}-0.031 \\
(0.479)\end{array}$ & $\begin{array}{c}-1.175^{\star *} \\
(0.583)\end{array}$ \\
\hline SGP*GDPdevq & & & & $\begin{array}{c}0.136^{* *} \\
(0.067)\end{array}$ & $\begin{array}{l}0.505^{\star * *} \\
(0.138)\end{array}$ & $\begin{array}{l}0.523^{* * *} \\
(0.162)\end{array}$ \\
\hline Constant & $\begin{array}{l}0.435^{\star *} \\
(0.202)\end{array}$ & $\begin{array}{l}1.121^{* * *} \\
(0.408)\end{array}$ & $\begin{array}{l}2.606^{\star * *} \\
(0.703)\end{array}$ & $\begin{array}{c}0.435^{\star *} \\
(0.203)\end{array}$ & $\begin{array}{l}1.085^{* *} \\
(0.423)\end{array}$ & $\begin{array}{l}2.609^{* * *} \\
(0.702)\end{array}$ \\
\hline Observations & 249 & 219 & 164 & 248 & 219 & 164 \\
\hline Countries & 26 & 26 & 25 & 26 & 26 & 25 \\
\hline $\mathrm{R}^{2}$ & 0.001 & 0.002 & 0.012 & 0.009 & 0.040 & 0.044 \\
\hline RMSE & 2.571 & 3.814 & 3.896 & 2.560 & 3.723 & 3.810 \\
\hline
\end{tabular}

Notes: ${ }^{* * *} \mathrm{p}<0.01,{ }^{* *} \mathrm{p}<0.05,{ }^{*} \mathrm{p}<0.1$. Robust standard errors in parentheses. Country random effects.

Table 5(b): GDP growth rate forecast error, western European countries

\begin{tabular}{lcccccc}
\hline Variables & $\begin{array}{c}\mathbf{1} \text { year } \\
\text { ahead }\end{array}$ & $\begin{array}{c}\mathbf{2} \text { years } \\
\text { ahead }\end{array}$ & $\begin{array}{c}\mathbf{3} \text { years } \\
\text { ahead }\end{array}$ & $\begin{array}{c}\mathbf{1} \text { year } \\
\text { ahead }\end{array}$ & $\begin{array}{c}\text { 2 years } \\
\text { ahead }\end{array}$ & $\begin{array}{c}\text { 3 years } \\
\text { ahead }\end{array}$ \\
\hline SGPdummy & $0.337^{*}$ & $0.963^{* * *}$ & $0.699^{* * *}$ & 0.153 & 0.364 & 0.204 \\
SGP*GDPdevq & $(0.193)$ & $(0.228)$ & $(0.175)$ & $(0.210)$ & $(0.274)$ & $(0.252)$ \\
& & & & $0.144^{* *}$ & $0.472^{* * *}$ & $0.477^{* * *}$ \\
Constant & 0.197 & $0.382^{*}$ & $0.814^{* * *}$ & $(0.069)$ & $(0.127)$ & $(0.135)$ \\
& $(0.191)$ & $(0.199)$ & $(0.077)$ & $(0.192)$ & $0.382^{*}$ & $0.814^{* * *}$ \\
Observations & 199 & 179 & 134 & 199 & 179 & $(0.078)$ \\
Countries & 16 & 16 & 15 & 16 & 16 & 134 \\
$\mathrm{R}^{2}$ & 0.008 & 0.040 & 0.017 & 0.031 & 0.168 & 0.136 \\
RMSE & 1.833 & 2.340 & 2.438 & 1.816 & 2.184 & 2.295 \\
\hline
\end{tabular}

Notes: ${ }^{* * *} p<0.01,{ }^{* *} p<0.05,{ }^{*} p<0.1$. Robust standard errors in parentheses. Random effects. 
Table 5(c): GDP growth rate forecast error, full dataset

\begin{tabular}{|c|c|c|c|c|c|c|}
\hline Variables & $\begin{array}{l}1 \text { year } \\
\text { ahead }\end{array}$ & $\begin{array}{c}2 \text { years } \\
\text { ahead }\end{array}$ & $\begin{array}{c}3 \text { years } \\
\text { ahead }\end{array}$ & $\begin{array}{l}1 \text { year } \\
\text { ahead }\end{array}$ & $\begin{array}{c}2 \text { years } \\
\text { ahead }\end{array}$ & $\begin{array}{c}3 \text { years } \\
\text { ahead }\end{array}$ \\
\hline SGPdummy & $\begin{array}{r}0.379^{*} \\
(0.199)\end{array}$ & $\begin{array}{l}0.780^{* *} \\
(0.352)\end{array}$ & $\begin{array}{c}-0.555 \\
(0.529)\end{array}$ & $\begin{array}{c}0.192 \\
(0.215)\end{array}$ & $\begin{array}{c}0.221 \\
(0.410)\end{array}$ & $\begin{array}{r}-1.067^{*} \\
(0.549)\end{array}$ \\
\hline SGP*GDPdevq & & & & $\begin{array}{c}0.148^{* *} \\
(0.068)\end{array}$ & $\begin{array}{l}0.516^{* * *} \\
(0.141)\end{array}$ & $\begin{array}{l}0.522^{\text {*** }} \\
(0.161)\end{array}$ \\
\hline Constant & $\begin{array}{c}0.239 \\
(0.168)\end{array}$ & $\begin{array}{l}0.914^{\star * *} \\
(0.318)\end{array}$ & $\begin{array}{c}2.436^{\star \star *} \\
(0.643)\end{array}$ & $\begin{array}{c}0.252 \\
(0.168)\end{array}$ & $\begin{array}{l}0.887^{\star \star *} \\
(0.330)\end{array}$ & $\begin{array}{l}2.444^{\star \star \star} \\
(0.642)\end{array}$ \\
\hline Observations & 369 & 282 & 175 & 368 & 282 & 175 \\
\hline Countries & 33 & 31 & 28 & 33 & 31 & 28 \\
\hline $\mathrm{R}^{2}$ & 0.006 & 0.006 & 0.007 & 0.011 & 0.042 & 0.040 \\
\hline RMSE & 2.404 & 3.439 & 3.811 & 2.375 & 3.358 & 3.726 \\
\hline
\end{tabular}

Notes: ${ }^{* *} p<0.01,{ }^{* *} p<0.05,{ }^{*} p<0.1$. Robust standard errors in parentheses. random effects. SGP $\equiv$ dummy for countries subject to the SGP. GDP devq $\equiv$ GDP as deviation from trend. All variables are lagged so that they line up with the year in which the forecast was made and not the year being forecast.

positive coefficient on the SGP dummy in Table 4(b) diminishes or even disappears when we include the interactive term. Evidently the boost that a budget rule gives to the optimism bias, above and beyond the bias in other countries, comes in booms.

We also tested for signs of forecast bias in potential member countries during the 5 years preceding successful entrance to the euro. We did find statistically significant upward bias in their growth forecasts, but no evidence of over-optimism in their budget forecasts (see Appendix Tables $3(a-d)$ ). A natural interpretation is that the political pressure of the Maastricht criteria was reflected in the actual ex post budget performance-or at least in the ex post budget numbers reported-because approval of admission was a successful enforcement mechanism, but that these governments had no incentive to exaggerate their prospects ahead of time.

\section{Are official forecasts overly optimistic at cyclical lows as well as highs?}

We have noted some evidence consistent with the idea that over-optimism thrives when genuine uncertainty is higher: the pattern whereby it increases with the horizon of the forecast. Uncertainty is probably greater at cyclical highs and lows, because it is difficult to tell whether the recent movement is temporary or permanent. These considerations suggest a further hypothesis worthy of testing: that forecasts are overly optimistic not just at the top of the business cycle, but at the bottom as well. The simplest way to test this hypothesis is to transform our cyclical independent variable, which has been expressed as the deviation of GDP from trend, to the absolute value of that deviation. Tables 6( $a$ and $b$ ) offer strong support for the hypothesis as a characterization of bias in official forecasts of the budget balance. Tables 7( $a$ and $b$ ) support the hypothesis for bias in official forecasts of economic growth. ( $\mathrm{R}^{2} \mathrm{~s}$ are higher, too.) Evidently official forecasters are overly optimistic both in booms and busts, more so than when GDP is at its long-run trend. They over-estimate the 
Table 6(a): Budget balance forecast error as a \% of GDP, full dataset

\begin{tabular}{lccc}
\hline Variables & 1 year ahead & 2 years ahead & 3 years ahead \\
\hline Absolute value of GDPdevq & 0.089 & $0.286^{\star \star *}$ & $0.342^{\star \star \star}$ \\
& $(0.050)$ & $(0.056)$ & $(0.097)$ \\
Constant & 0.088 & 0.078 & $0.742^{\star *}$ \\
& $(0.159)$ & $(0.254)$ & $(0.319)$ \\
Observations & 398 & 300 & 179 \\
Countries & 33 & 31 & 29 \\
R $^{2}$ & 0.007 & 0.060 & 0.066 \\
RMSE & 2.108 & 2.630 & 3.021 \\
\hline
\end{tabular}

Notes: GDP devq $\equiv$ GDP as deviation from quadratic trend. ${ }^{* *} p<0.01,{ }^{* *} p<0.05,{ }^{*} p<0.1$. Robust standard errors in parentheses. Country random effects.

Table 6(b): Budget balance forecast error as a \% of GDP, European countries

\begin{tabular}{lccc}
\hline Variables & 1 year ahead & 2 years ahead & 3 years ahead \\
\hline Absolute value of GDPdevq & $0.169^{* * *}$ & $0.313^{* * *}$ & $0.410^{* * *}$ \\
& $(0.052)$ & $(0.074)$ & $(0.103)$ \\
Constant & 0.185 & 0.353 & $0.781^{* *}$ \\
& $(0.168)$ & $(0.263)$ & $(0.330)$ \\
Observations & 254 & 221 & 164 \\
$R^{2}$ & 0.062 & 0.103 & 0.106 \\
RMSE & 2.227 & 2.905 & 3.056 \\
\hline
\end{tabular}

Notes: GDP devq $\equiv$ GDP as deviation from quadratic trend. ${ }^{* *} p<0.01,{ }^{* *} p<0.05,{ }^{*} p<0.1$. Robust standard errors in parentheses. Random effects.

Table 7(a): GDP growth rate forecast error, full dataset

\begin{tabular}{lccc}
\hline Variables & 1 year ahead & 2 years ahead & 3 years ahead \\
\hline Absolute value of GDPdevq & 0.133 & $0.531^{* * *}$ & $0.743^{* * *}$ \\
& $(0.106)$ & $(0.114)$ & $(0.233)$ \\
Constant & -0.019 & -0.255 & 0.133 \\
& $(0.242)$ & $(0.314)$ & $(0.491)$ \\
Observations & 368 & 282 & 175 \\
R $^{2}$ & 0.035 & 0.201 & 0.220 \\
RMSE & 2.363 & 3.142 & 3.594 \\
\hline
\end{tabular}

Note: GDP devq $\equiv$ GDP as deviation from quadratic trend.

Table 7(b): GDP growth rate forecast error, European countries

\begin{tabular}{lccc}
\hline Variables & 1 year ahead & 2 years ahead & 3 years ahead \\
\hline Absolute value of GDPdevq & $0.250^{* * *}$ & $0.606^{* * *}$ & $0.824^{* * *}$ \\
& $(0.041)$ & $(0.093)$ & $(0.212)$ \\
Constant & -0.137 & -0.206 & 0.0932 \\
& $(0.156)$ & $(0.281)$ & $(0.448)$ \\
Observations & 248 & 219 & 164 \\
$\mathrm{R}^{2}$ & 0.111 & 0.246 & 0.257 \\
RMSE & 2.420 & 3.355 & 3.587 \\
\hline
\end{tabular}

Notes: GDP devq $\equiv$ GDP as deviation from quadratic trend. ${ }^{* *} p<0.01,{ }^{* *} p<0.05,{ }^{*} p<0.1$. Robust standard errors in parentheses, clustered by country. 
permanence of the booms and the transitoriness of the busts. The pattern is worse for Europeans than for others.

\section{Proposed solution: follow Chile in insulating budget forecasting from politics}

We have hypothesized that one reason advanced countries have sometimes run excessive deficits in periods of expansion is excessive optimism in official forecasts of growth rates and budgets. We then supported the hypothesis with statistical evidence of precisely such a bias. The paper began, however, by noting that some countries in the South have since 2000 managed to achieve countercyclical policy, taking advantage of the 2002-7 boom years to attain surpluses. This achievement is all the more remarkable among countries dependent on exports of minerals and other commodities, because they are the ones that have historically been especially procyclical. How have they done it?

Consider the especially instructive example of Chile, a country highly dependent on volatile copper exports. ${ }^{20}$ During the years 2003-8 copper prices rose, the economy grew strongly, and government revenues increased rapidly. Unlike so many other commodity exporting countries in the past, Chile saved most of this bonanza. Public saving and national saving both rose strongly. Government debt fell and the sovereign spread gradually declined. By 2007 Chile had become a net creditor. Its sovereign debt rating climbed above that of its Latin American neighbours and even ahead of some advanced countries.

By the time copper prices reached a peak in 2008, the political pressure on the government to spend the revenue had become intense. The insistence of the government on saving the money for a 'rainy day' helped push its poll ratings to very low levels. In 2009, the global recession hit, copper prices fell sharply, and the Chilean economy turned down as well. Yet, in the span of 1 year, the polls reversed dramatically: the President and her Finance Minister attained the highest popularity rating of any officials since the restoration of democracy in Chile 20 years earlier. The reason is that, now that the rainy day had arrived, the government increased spending liberally, thereby moderating the downturn. It was in a good position to do this, with no loss to its creditworthiness, because of the exemplary saving that had come before.

How was Chile able to achieve a countercyclical fiscal policy during the years 2000-10? The actions of individual leaders were important. But equally important was an institutional framework within which the political process operated. Chile introduced a structural balance regime for fiscal policy in 2000 and codified it legally in 2006. Under this regime the government must set a structural budget target. It can run a deficit larger than the target only to the extent that: (i) output falls short of its long-run trend, in a recession, or (ii) the price of copper is below its 10-year trend. If GDP and the price of copper are above their long-run trends, the government must save the resulting revenue in the form of surpluses. The key institutional innovation is that there are two panels of experts whose job it is each mid-year to make the judgements, respectively, what is the output gap and what is the medium-term equilibrium price of copper, rather than leaving the job to government officials.

\footnotetext{
${ }^{20}$ Frankel (2011) explains Chile's structural budget rule in greater detail and gives further references.
} 
Chile's official forecasts have not been subject to the same bias towards over-optimism that typifies other countries. If anything, its forecasts have erred on the pessimistic side. The official forecast of real growth has fallen short of the ex post numbers by an average of 0.8 per cent at the 1-year horizon. The official forecast of the budget surplus as a percentage of GDP has fallen short of the ex post numbers by an average of 1.4 per cent at the 1-year horizon (1977-2009). In Figure 1(a), the observations corresponding to Chile are indicated by Xs. Most lie below the line of zero budget forecast errors and almost all of those that lie above miss by only a small margin. There is no tendency for the forecast error to rise in booms, as with other countries.

Chile's fiscal institutions have apparently enabled it to avoid the problem of official forecasts that fall prey to wishful thinking. Downturns or budget deficits are not explained away with unrealistic forecasts of dramatic improvement; booms and surpluses are not unrealistically extrapolated into the future.

Any country could usefully apply variants of the Chilean fiscal device. Countries could set up independent institutions charged by law with estimating the output gap and such other budget-relevant macroeconomic variables as the inflation rate and the fractions of GDP going to wage versus non-wage income. A useful reinforcement of the Chilean idea would be to give the panels legal independence. There could be laws protecting them from being fired, as there are for governors of independent central banks. One could imagine also broadening the responsibility of such panels beyond simply estimating the long-run trend in income. The principle of a separation of decision-making powers should be retained, however: only elected political leaders can determine how spending is allocated or taxes are raised.

The United Kingdom in 2010 established an Office of Budgetary Responsibility (OBR), designed explicitly to be independent and free of political bias. In addition to making forecasts, the OBR scrutinizes the Treasury's costing of budget measures, judges progress towards the Government's fiscal targets, and assesses the long-term sustainability of the public finances. The US Congressional Budget Office (CBO), in addition to making forecasts, estimates the fiscal impact of any sort of proposed measures and undertakes a wide variety of research to aid in federal economic and budgetary decisions.

Formal independence is no guarantee that fiscal over-optimism will be eliminated. For one thing, analysts can make mistakes even if independent. For another thing, politicians can sometimes 'game' the institution. For example, US politicians have legislated tax cuts with phony expiration dates to force the $\mathrm{CBO}$ to issue a baseline forecast of limited revenue loss, even while they publicly declare their intention to extend the tax cuts when the date of expiration arrives.

Nevertheless the results of this paper suggest that any institutions that could insulate budget forecasts from political temptations and make them more realistic could eliminate a systematic tendency towards over-optimism that in many countries has contributed to excessive budget deficits in expansions. 
Appendix Table 1: Errors in forecasting budget surplus (official forecast - actual) expressed as \% of GDP

\begin{tabular}{|c|c|c|c|c|c|}
\hline & & $\begin{array}{l}\text { Actual fiscal } \\
\text { balance }\end{array}$ & $\begin{array}{c}1 \text { year ahead } \\
\text { budget } \\
\text { forecast error }\end{array}$ & $\begin{array}{l}2 \text { year ahead } \\
\text { budget } \\
\text { forecast error }\end{array}$ & $\begin{array}{c}3 \text { year ahead } \\
\text { budget } \\
\text { forecast error }\end{array}$ \\
\hline Australia & Mean & -0.2 & -0.2 & -0.2 & 1.2 \\
\hline \multirow[t]{3}{*}{ 1985-2009 } & Min & -2.7 & -1.6 & -1.4 & -0.9 \\
\hline & Max & 1.7 & 4.0 & 3.3 & 3.2 \\
\hline & Obs & 26 & 25 & 14 & 2 \\
\hline Austria & Mean & -1.8 & 0.3 & 0.7 & 0.9 \\
\hline \multirow[t]{3}{*}{ 1999-2009 } & Min & -3.9 & -0.6 & -1.3 & -1.3 \\
\hline & Max & -0.2 & 3.2 & 3.3 & 4.1 \\
\hline & Obs & 13 & 11 & 10 & 9 \\
\hline Belgium & Mean & -1.0 & 0.2 & 1.0 & 1.3 \\
\hline \multirow[t]{3}{*}{ 1999-2009 } & Min & -5.9 & -1.1 & -1.1 & -1.0 \\
\hline & Max & 0.3 & 2.4 & 6.2 & 6.6 \\
\hline & Obs & 13 & 11 & 10 & 9 \\
\hline Canada & Mean & -2.1 & -0.9 & -0.7 & NA \\
\hline \multirow[t]{3}{*}{ 1985-2008 } & Min & -8.6 & -2.6 & -2.5 & NA \\
\hline & Max & 1.3 & 0.5 & 1.7 & NA \\
\hline & Obs & 26 & 23 & 20 & 0 \\
\hline Chile & Mean & 2.2 & -1.4 & NA & NA \\
\hline \multirow[t]{3}{*}{ 1977-2009 } & Min & -5.5 & -8.3 & NA & NA \\
\hline & Max & 8.9 & 8.1 & NA & NA \\
\hline & Obs & 33 & 33 & 0 & 0 \\
\hline Cyprus & Mean & -2.8 & -0.2 & -0.4 & -0.4 \\
\hline \multirow[t]{3}{*}{ 2005-9 } & Min & -6.5 & -4.9 & -5.1 & -4.8 \\
\hline & Max & 3.3 & 5.3 & 6.6 & 5.7 \\
\hline & Obs & 12 & 5 & 4 & 3 \\
\hline Czech Republic & Mean & -4.2 & -0.1 & -0.3 & 0.4 \\
\hline \multirow[t]{3}{*}{$2005-9$} & Min & -6.8 & -2.4 & -1.9 & -1.7 \\
\hline & Max & -1.6 & 5.0 & 3.6 & 3.6 \\
\hline & Obs & 13 & 5 & 4 & 3 \\
\hline Denmark & Mean & 1.6 & 0.1 & 0.2 & 0.1 \\
\hline \multirow{3}{*}{ 1999-2008 } & Min & -3.0 & -2.8 & -3.1 & -2.8 \\
\hline & Max & 4.8 & 3.0 & 5.0 & 4.8 \\
\hline & Obs & 13 & 11 & 10 & 9 \\
\hline Estonia & Mean & 0.3 & -0.3 & 0.4 & 1.4 \\
\hline \multirow[t]{3}{*}{$2005-9$} & Min & -3.5 & -3.3 & -3.4 & -2.8 \\
\hline & Max & 3.4 & 4.1 & 4.1 & 4.2 \\
\hline & Obs & 13 & 5 & 4 & 3 \\
\hline Finland & Mean & 2.8 & -0.5 & -0.8 & -0.3 \\
\hline \multirow[t]{3}{*}{ 1999-2009 } & Min & -2.2 & -2.5 & -4.7 & -3.1 \\
\hline & Max & 6.9 & 4.3 & 5.8 & 4.9 \\
\hline & Obs & 13 & 11 & 10 & 9 \\
\hline France & Mean & -3.5 & 0.6 & 1.5 & 2.2 \\
\hline \multirow[t]{3}{*}{ 1996-2009 } & Min & -7.9 & -0.5 & -0.4 & 0.1 \\
\hline & Max & -1.5 & 4.0 & 6.2 & 7.0 \\
\hline & Obs & 16 & 14 & 10 & 9 \\
\hline Germany & Mean & -3.0 & 1.0 & 1.4 & 1.3 \\
\hline \multirow[t]{3}{*}{ 1991-2009 } & Min & -4.8 & -1.7 & -2.5 & -2.0 \\
\hline & Max & 0.0 & 3.5 & 3.4 & 3.8 \\
\hline & Obs & 19 & 19 & 18 & 9 \\
\hline Greece & Mean & -5.5 & 4.3 & 5.4 & 6.0 \\
\hline \multirow[t]{3}{*}{ 2000-9 } & Min & -12.7 & 0.3 & 0.1 & 0.9 \\
\hline & Max & -2.9 & 9.0 & 11.9 & 11.5 \\
\hline & Obs & 13 & 10 & 9 & 8 \\
\hline
\end{tabular}




\begin{tabular}{|c|c|c|c|c|c|}
\hline & & $\begin{array}{c}\text { Actual fiscal } \\
\text { balance }\end{array}$ & $\begin{array}{c}1 \text { year ahead } \\
\text { budget } \\
\text { forecast error }\end{array}$ & $\begin{array}{c}2 \text { year ahead } \\
\text { budget } \\
\text { forecast error }\end{array}$ & $\begin{array}{c}3 \text { year ahead } \\
\text { budget } \\
\text { forecast error }\end{array}$ \\
\hline Hungary & Mean & -6.1 & 1.7 & 2.2 & 1.9 \\
\hline \multirow[t]{3}{*}{$2005-9$} & Min & -9.3 & -1.3 & -0.5 & 0.7 \\
\hline & Max & -3.0 & 4.6 & 6.2 & 3.1 \\
\hline & Obs & 13 & 5 & 4 & 3 \\
\hline Ireland & Mean & 0.0 & 0.4 & 1.0 & 1.9 \\
\hline \multirow[t]{3}{*}{ 1999-2009 } & Min & -11.7 & -3.6 & -3.6 & -4.1 \\
\hline & Max & 4.7 & 6.3 & 10.6 & 12.3 \\
\hline & Obs & 13 & 11 & 10 & 9 \\
\hline Italy & Mean & -7.9 & 1.1 & 1.6 & 2.6 \\
\hline \multirow[t]{3}{*}{ 1990-2009 } & Min & -18.1 & -3.8 & -3.5 & 0.5 \\
\hline & Max & -1.8 & 5.8 & 5.2 & 4.2 \\
\hline & Obs & 25 & 20 & 19 & 9 \\
\hline Latvia & Mean & -2.1 & 1.5 & 2.9 & 3.7 \\
\hline \multirow[t]{3}{*}{ 2005-9 } & Min & -10.0 & -1.3 & -1.4 & -1.4 \\
\hline & Max & 1.4 & 6.5 & 11.0 & 9.6 \\
\hline & Obs & 13 & 5 & 4 & 3 \\
\hline Lithuania & Mean & -3.4 & 1.4 & 2.7 & 3.7 \\
\hline \multirow{3}{*}{ 2005-9 } & Min & -11.9 & -2.0 & -1.3 & -0.3 \\
\hline & Max & -0.5 & 7.0 & 9.3 & 9.1 \\
\hline & Obs & 13 & 5 & 4 & 3 \\
\hline Luxemburg & Mean & 2.3 & -1.7 & -1.4 & -0.7 \\
\hline \multirow[t]{3}{*}{ 1999-2009 } & Min & -1.2 & -4.8 & -4.8 & -4.8 \\
\hline & Max & 6.1 & 2.2 & 2.6 & 4.6 \\
\hline & Obs & 13 & 11 & 10 & 9 \\
\hline Malta & Mean & -5.7 & 0.9 & 1.8 & 2.6 \\
\hline \multirow[t]{3}{*}{ 2005-9 } & Min & -9.9 & -0.7 & -0.5 & 0.4 \\
\hline & Max & -1.8 & 3.5 & 3.8 & 3.9 \\
\hline & Obs & 13 & 5 & 4 & 3 \\
\hline Mexico & Mean & -0.6 & 0.1 & NA & NA \\
\hline \multirow{3}{*}{ 1995-2009 } & Min & -2.3 & -0.1 & NA & NA \\
\hline & Max & 0.1 & 0.6 & NA & NA \\
\hline & Obs & 15 & 15 & 0 & 0 \\
\hline Netherlands & Mean & -2.7 & 0.6 & 0.4 & 0.7 \\
\hline \multirow[t]{3}{*}{ 1995-2009 } & Min & -11.0 & -2.3 & -2.6 & -2.3 \\
\hline & Max & 1.3 & 7.1 & 5.5 & 5.8 \\
\hline & Obs & 17 & 15 & 10 & 9 \\
\hline New Zealand & Mean & 1.9 & -0.1 & -0.4 & -0.8 \\
\hline \multirow[t]{3}{*}{ 1995-2008 } & Min & -0.9 & -4.2 & -3.9 & -0.8 \\
\hline & Max & 7.3 & 2.9 & 3.9 & -0.8 \\
\hline & Obs & 18 & 13 & 12 & 1 \\
\hline Poland & Mean & -4.4 & 1.6 & 2.1 & 2.7 \\
\hline \multirow[t]{3}{*}{ 2005-9 } & Min & -7.2 & 0.4 & -0.2 & -0.2 \\
\hline & Max & -2.0 & 4.7 & 5.2 & 6.6 \\
\hline & Obs & 13 & 5 & 4 & 3 \\
\hline Portugal & Mean & -3.9 & 1.4 & 2.3 & 3.1 \\
\hline \multirow[t]{3}{*}{ 1999-2009 } & Min & -9.3 & -1.0 & -1.0 & 0.1 \\
\hline & Max & -2.7 & 5.4 & 7.8 & 7.8 \\
\hline & Obs & 13 & 11 & 10 & 9 \\
\hline Slovakia & Mean & -5.2 & 0.5 & 1.4 & 1.9 \\
\hline \multirow[t]{3}{*}{ 2005-9 } & Min & -12.2 & -0.7 & -0.1 & 0.3 \\
\hline & Max & -2.2 & 3.3 & 4.5 & 4.4 \\
\hline & Obs & 13 & 5 & 4 & 3 \\
\hline
\end{tabular}




\begin{tabular}{|c|c|c|c|c|c|}
\hline & & $\begin{array}{l}\text { Actual fiscal } \\
\text { balance }\end{array}$ & $\begin{array}{c}1 \text { year ahead } \\
\text { budget } \\
\text { forecast error }\end{array}$ & $\begin{array}{l}2 \text { year ahead } \\
\text { budget } \\
\text { forecast error }\end{array}$ & $\begin{array}{c}3 \text { year ahead } \\
\text { budget } \\
\text { forecast error }\end{array}$ \\
\hline Slovenia & Mean & -2.6 & -0.2 & 0.9 & 1.5 \\
\hline \multirow[t]{3}{*}{ 2005-9 } & Min & -5.7 & -1.4 & -1.3 & -1.0 \\
\hline & Max & -0.1 & 0.9 & 5.1 & 4.7 \\
\hline & Obs & 13 & 5 & 4 & 3 \\
\hline South Africa & Mean & -1.6 & -0.3 & -1.3 & -1.5 \\
\hline \multirow[t]{3}{*}{ 1998-2008 } & Min & -5.2 & -2.8 & -4.0 & -4.4 \\
\hline & Max & 1.7 & 5.6 & 0.9 & 0.2 \\
\hline & Obs & 13 & 11 & 10 & 9 \\
\hline Spain & Mean & -1.6 & 0.9 & 1.5 & 1.6 \\
\hline \multirow[t]{3}{*}{ 1999-2009 } & Min & -11.4 & -1.2 & -1.6 & -1.8 \\
\hline & Max & 2.2 & 5.6 & 12.6 & 12.3 \\
\hline & Obs & 13 & 11 & 10 & 9 \\
\hline Sweden & Mean & 0.8 & 0.4 & 0.7 & 1.4 \\
\hline \multirow[t]{3}{*}{ 1998-2009 } & Min & -2.2 & -1.7 & -2.3 & -2.5 \\
\hline & Max & 3.8 & 3.5 & 5.3 & 5.3 \\
\hline & Obs & 14 & 12 & 11 & 9 \\
\hline Switzerland & Mean & -0.4 & -0.2 & -0.2 & NA \\
\hline \multirow[t]{3}{*}{ 1990-2003 } & Min & -2.2 & -2.9 & -2.3 & NA \\
\hline & Max & 0.8 & 1.4 & 1.0 & NA \\
\hline & Obs & 16 & 14 & 13 & 0 \\
\hline United Kingdom & Mean & -3.0 & 0.8 & 1.8 & 2.8 \\
\hline \multirow[t]{3}{*}{ 1997-2009 } & Min & -12.6 & -1.4 & -1.9 & -0.7 \\
\hline & Max & 2.7 & 4.5 & 10.2 & 10.9 \\
\hline & Obs & 25 & 13 & 11 & 9 \\
\hline United States & Mean & -2.7 & 0.4 & 1.0 & 3.1 \\
\hline \multirow[t]{3}{*}{ 1986-2009 } & Min & -9.9 & -2.2 & -3.1 & -0.6 \\
\hline & Max & 2.6 & 7.2 & 8.7 & 8.5 \\
\hline & Obs & 26 & 24 & 23 & 3 \\
\hline \multirow[t]{4}{*}{ Total } & Mean & -1.9 & 0.2 & 0.8 & 1.5 \\
\hline & Min & -18.1 & -8.3 & -5.1 & -4.8 \\
\hline & Max & 8.9 & 9.0 & 12.6 & 12.3 \\
\hline & Obs & 535 & 399 & 300 & 179 \\
\hline
\end{tabular}

Note: Years are those for which we have data for the 1 year ahead budget forecast error.

Appendix Table 2: Errors in forecasting GDP growth rate (official forecast - actual)

\begin{tabular}{llcccc}
\hline & $\begin{array}{c}\text { Actual GDP } \\
\text { growth rate }\end{array}$ & $\begin{array}{c}\text { 1 year ahead } \\
\text { GDP growth rate } \\
\text { forecast error }\end{array}$ & $\begin{array}{c}\text { 2 year ahead } \\
\text { GDP growth } \\
\text { rate forecast error }\end{array}$ & $\begin{array}{c}\text { 3 year ahead } \\
\text { GDP growth } \\
\text { rate forecast error }\end{array}$ \\
\hline Australia & Mean & 3.1 & 0.2 & 0.8 & NA \\
$\mathbf{1 9 8 7 - 2 0 0 9}$ & Min & -0.8 & -2.0 & 0.4 & NA \\
& Max & 4.6 & 2.8 & 1.1 & NA \\
& Obs & 24 & 23 & 2 & 0 \\
\hline
\end{tabular}




\begin{tabular}{|c|c|c|c|c|c|}
\hline & & $\begin{array}{l}\text { Actual GDP } \\
\text { growth rate }\end{array}$ & $\begin{array}{l}1 \text { year ahead } \\
\text { GDP growth rate } \\
\text { forecast error }\end{array}$ & $\begin{array}{l}2 \text { year ahead } \\
\text { GDP growth } \\
\text { rate forecast error }\end{array}$ & $\begin{array}{l}3 \text { year ahead } \\
\text { GDP growth } \\
\text { rate forecast error }\end{array}$ \\
\hline Austria & Mean & 1.9 & 0.1 & 0.9 & 1.0 \\
\hline \multirow[t]{3}{*}{ 1999-2009 } & Min & -3.4 & -1.5 & -1.0 & -1.2 \\
\hline & Max & 3.6 & 2.0 & 5.9 & 5.9 \\
\hline & Obs & 13 & 11 & 10 & 9 \\
\hline Belgium & Mean & 1.8 & 0.0 & 0.9 & 1.1 \\
\hline \multirow[t]{3}{*}{ 1999-2009 } & Min & -3.1 & -1.2 & -1.4 & -0.6 \\
\hline & Max & 3.7 & 1.7 & 5.1 & 5.3 \\
\hline & Obs & 13 & 11 & 10 & 9 \\
\hline Canada & Mean & 2.9 & -0.3 & 0.4 & NA \\
\hline \multirow{3}{*}{ 1985-2003 } & Min & -1.7 & -3.3 & -2.6 & NA \\
\hline & Max & 5.1 & 2.0 & 4.7 & NA \\
\hline & Obs & 21 & 18 & 17 & 0 \\
\hline Chile & Mean & 4.9 & -0.8 & NA & NA \\
\hline \multirow[t]{3}{*}{$1981,1985-2008$} & Min & -10.3 & -7.3 & NA & NA \\
\hline & Max & 12.3 & 4.6 & NA & NA \\
\hline & Obs & 28 & 25 & 0 & 0 \\
\hline Cyprus & Mean & 3.3 & 0.7 & 1.6 & 2.3 \\
\hline \multirow[t]{3}{*}{$2005-9$} & Min & -1.7 & -0.5 & 0.1 & 0.4 \\
\hline & Max & 5.9 & 3.8 & 5.7 & 5.8 \\
\hline & Obs & 13 & 5 & 4 & 3 \\
\hline Czech Republic & Mean & 2.6 & 0.8 & 1.7 & 2.6 \\
\hline \multirow[t]{3}{*}{$2005-9$} & Min & -4.0 & -2.8 & -2.5 & -2.7 \\
\hline & Max & 6.5 & 7.7 & 9.0 & 8.8 \\
\hline & Obs & 13 & 5 & 4 & 3 \\
\hline Denmark & Mean & 1.4 & 0.5 & 0.6 & 1.0 \\
\hline \multirow[t]{3}{*}{ 1999-2009 } & Min & -4.3 & -1.9 & -2.6 & -2.0 \\
\hline & Max & 3.9 & 4.1 & 5.4 & 5.0 \\
\hline & Obs & 13 & 11 & 10 & 9 \\
\hline Estonia & Mean & 5.2 & 2.4 & 6.5 & 10.3 \\
\hline \multirow[t]{3}{*}{ 2005-9 } & Min & -14.5 & -4.6 & -5.2 & -1.1 \\
\hline & Max & 11.2 & 11.0 & 20.6 & 22.1 \\
\hline & Obs & 13 & 5 & 4 & 3 \\
\hline Finland & Mean & 2.7 & 0.7 & 0.7 & 0.9 \\
\hline \multirow[t]{3}{*}{ 1999-2009 } & Min & -7.6 & -1.7 & -2.5 & -2.5 \\
\hline & Max & 6.1 & 8.2 & 10.6 & 10.2 \\
\hline & Obs & 13 & 11 & 10 & 9 \\
\hline France & Mean & 1.7 & 0.6 & 1.0 & 1.3 \\
\hline \multirow[t]{3}{*}{ 1998-2009 } & Min & -2.3 & -0.9 & -1.4 & 0.0 \\
\hline & Max & 3.9 & 2.7 & 4.8 & 4.6 \\
\hline & Obs & 14 & 12 & 10 & 9 \\
\hline Germany & Mean & 1.4 & 0.9 & 1.2 & 1.7 \\
\hline \multirow[t]{3}{*}{ 1992-2009 } & Min & -5.0 & -1.5 & -1.5 & -0.7 \\
\hline & Max & 3.9 & 5.2 & 6.5 & 6.8 \\
\hline & Obs & 20 & 18 & 18 & 9 \\
\hline Greece & Mean & 3.5 & 0.2 & 0.7 & 0.9 \\
\hline \multirow[t]{3}{*}{$2000-9$} & Min & -1.2 & -1.2 & -1.0 & -0.6 \\
\hline & Max & 5.0 & 2.3 & 5.2 & 5.3 \\
\hline & Obs & 13 & 10 & 9 & 8 \\
\hline Hungary & Mean & 3.0 & 1.8 & 4.0 & 5.8 \\
\hline \multirow[t]{3}{*}{ 2005-9 } & Min & -6.7 & -0.1 & 0.3 & 3.0 \\
\hline & Max & 5.2 & 5.8 & 10.7 & 10.9 \\
\hline & Obs & 13 & 5 & 4 & 3 \\
\hline
\end{tabular}




\begin{tabular}{|c|c|c|c|c|c|}
\hline & & $\begin{array}{l}\text { Actual GDP } \\
\text { growth rate }\end{array}$ & $\begin{array}{l}1 \text { year ahead } \\
\text { GDP growth rate } \\
\text { forecast error }\end{array}$ & $\begin{array}{l}2 \text { year ahead } \\
\text { GDP growth } \\
\text { rate forecast error }\end{array}$ & $\begin{array}{l}3 \text { year ahead } \\
\text { GDP growth } \\
\text { rate forecast error }\end{array}$ \\
\hline Ireland & Mean & 5.4 & 0.0 & 1.2 & 1.7 \\
\hline \multirow[t]{3}{*}{ 1999-2009 } & Min & -7.5 & -3.7 & -2.9 & -1.0 \\
\hline & Max & 11.4 & 6.7 & 11.0 & 11.5 \\
\hline & Obs & 13 & 11 & 10 & 9 \\
\hline Italy & Mean & 1.7 & 0.7 & 1.3 & 2.3 \\
\hline \multirow[t]{3}{*}{ 1991-2009 } & Min & -4.8 & -1.4 & -0.9 & 0.7 \\
\hline & Max & 4.8 & 2.8 & 6.4 & 6.4 \\
\hline & Obs & 25 & 18 & 17 & 9 \\
\hline Latvia & Mean & 4.9 & 3.2 & 6.9 & 11.2 \\
\hline \multirow[t]{3}{*}{ 2005-9 } & Min & -18.0 & -5.4 & -6.4 & -3.6 \\
\hline & Max & 12.9 & 13.0 & 25.0 & 25.5 \\
\hline & Obs & 13 & 5 & 4 & 3 \\
\hline Lithuania & Mean & 4.8 & 1.5 & 4.3 & 7.0 \\
\hline \multirow[t]{3}{*}{ 2005-9 } & Min & -15.0 & -2.3 & -3.3 & -2.6 \\
\hline & Max & 10.4 & 10.2 & 19.5 & 19.5 \\
\hline & Obs & 13 & 5 & 4 & 3 \\
\hline Luxemburg & Mean & 4.3 & -0.1 & 0.9 & 1.6 \\
\hline \multirow[t]{3}{*}{ 1999-2009 } & Min & -3.9 & -5.2 & -4.7 & -2.3 \\
\hline & Max & 8.6 & 6.9 & 8.9 & 7.9 \\
\hline & Obs & 13 & 11 & 10 & 9 \\
\hline Malta & Mean & 2.5 & -0.3 & -0.1 & 0.8 \\
\hline \multirow[t]{3}{*}{ 2005-9 } & Min & -2.5 & -3.8 & -3.5 & -2.5 \\
\hline & Max & 8.1 & 4.2 & 5.2 & 5.1 \\
\hline & Obs & 13 & 5 & 4 & 3 \\
\hline Mexico & Mean & 1.5 & 1.7 & NA & NA \\
\hline \multirow{3}{*}{ 2003-9 } & Min & -6.5 & -1.2 & NA & NA \\
\hline & Max & 4.8 & 9.5 & NA & NA \\
\hline & Obs & 8 & 7 & 0 & 0 \\
\hline Netherlands & Mean & 2.1 & 0.2 & 0.8 & 1.1 \\
\hline \multirow[t]{3}{*}{ 1995-2009 } & Min & -4.0 & -2.5 & -1.8 & -1.0 \\
\hline & Max & 4.7 & 5.3 & 5.8 & 5.8 \\
\hline & Obs & 17 & 15 & 10 & 9 \\
\hline New Zealand & Mean & 2.8 & -0.3 & 0.3 & 0.4 \\
\hline \multirow[t]{3}{*}{ 1998-2008 } & Min & 0.0 & -1.7 & -1.1 & 0.4 \\
\hline & Max & 4.6 & 2.7 & 4.2 & 0.4 \\
\hline & Obs & 13 & 11 & 10 & 1 \\
\hline Poland & Mean & 4.3 & 0.1 & 0.0 & 1.0 \\
\hline \multirow[t]{3}{*}{ 2005-9 } & Min & 1.2 & -1.9 & -1.9 & -0.9 \\
\hline & Max & 7.1 & 2.0 & 3.3 & 3.9 \\
\hline & Obs & 13 & 5 & 4 & 3 \\
\hline Portugal & Mean & 1.7 & 0.7 & 1.9 & 2.5 \\
\hline \multirow[t]{3}{*}{ 1999-2009 } & Min & -2.7 & -0.6 & -0.7 & 0.9 \\
\hline & Max & 4.8 & 2.2 & 5.5 & 5.7 \\
\hline & Obs & 13 & 11 & 10 & 9 \\
\hline Slovakia & Mean & 4.2 & 0.0 & 0.7 & 1.7 \\
\hline \multirow[t]{3}{*}{ 2005-9 } & Min & -5.7 & -3.3 & -4.3 & -5.0 \\
\hline & Max & 10.4 & 8.1 & 11.5 & 10.8 \\
\hline & Obs & 13 & 5 & 4 & 3 \\
\hline & Mean & 3.4 & 0.1 & 2.1 & 3.2 \\
\hline \multirow{3}{*}{ 2005-9 } & Min & -7.3 & -1.8 & -2.1 & -2.1 \\
\hline & Max & 6.1 & 3.3 & 11.4 & 11.4 \\
\hline & Obs & 13 & 5 & 4 & 3 \\
\hline
\end{tabular}




\begin{tabular}{|c|c|c|c|c|c|}
\hline & & $\begin{array}{l}\text { Actual GDP } \\
\text { growth rate }\end{array}$ & $\begin{array}{l}1 \text { year ahead } \\
\text { GDP growth rate } \\
\text { forecast error }\end{array}$ & $\begin{array}{l}2 \text { year ahead } \\
\text { GDP growth } \\
\text { rate forecast error }\end{array}$ & $\begin{array}{l}3 \text { year ahead } \\
\text { GDP growth } \\
\text { rate forecast error }\end{array}$ \\
\hline South Africa & Mean & 3.2 & 0.2 & 0.1 & 0.1 \\
\hline \multirow[t]{3}{*}{ 1998-2008 } & Min & 0.4 & -1.5 & -1.7 & -1.6 \\
\hline & Max & 5.6 & 2.6 & 2.7 & 2.8 \\
\hline & Obs & 13 & 11 & 10 & 8 \\
\hline Spain & Mean & 3.0 & 0.0 & 0.5 & 0.8 \\
\hline \multirow[t]{3}{*}{ 1999-2009 } & Min & -3.6 & -1.4 & -1.8 & -0.9 \\
\hline & Max & 5.1 & 2.2 & 6.6 & 6.9 \\
\hline & Obs & 13 & 11 & 10 & 9 \\
\hline Sweden & Mean & 2.2 & 0.4 & 0.4 & 0.7 \\
\hline \multirow[t]{3}{*}{ 1998-2009 } & Min & -5.2 & -2.4 & -2.2 & -1.8 \\
\hline & Max & 4.6 & 6.5 & 7.7 & 7.9 \\
\hline & Obs & 14 & 12 & 11 & 9 \\
\hline Switzerland & Mean & 1.1 & 0.9 & 1.1 & NA \\
\hline \multirow[t]{3}{*}{ 1990-2003 } & Min & -0.7 & -1.6 & -1.4 & NA \\
\hline & Max & 3.4 & 2.7 & 2.7 & NA \\
\hline & Obs & 16 & 14 & 13 & 0 \\
\hline United Kingdom & Mean & 2.1 & 0.0 & 0.7 & 0.9 \\
\hline \multirow[t]{3}{*}{ 1998-2009 } & Min & -4.8 & -2.0 & -1.5 & -1.0 \\
\hline & Max & 3.8 & 3.8 & 7.6 & 7.3 \\
\hline & Obs & 13 & 12 & 11 & 9 \\
\hline United States & Mean & 2.7 & 0.5 & 0.6 & 3.8 \\
\hline \multirow[t]{3}{*}{ 1985-2009 } & Min & -2.5 & -3.1 & -3.1 & 1.9 \\
\hline & Max & 7.0 & 5.5 & 5.6 & 5.6 \\
\hline & Obs & 27 & 25 & 24 & 2 \\
\hline \multirow[t]{4}{*}{ Total } & Mean & 2.9 & 0.4 & 1.1 & 1.8 \\
\hline & Min & -18.0 & -7.3 & -6.4 & -5.0 \\
\hline & Max & 12.9 & 13.0 & 25.0 & 25.5 \\
\hline & Obs & 500 & 369 & 282 & 175 \\
\hline
\end{tabular}

Note: Years are those for which we have data for the 1 year ahead GDP growth forecast error.

Appendix Table 3(a): Budget balance forecast error as a \% of GDP, full dataset

\begin{tabular}{lccc}
\hline Variables & $\mathbf{1}$ year ahead & 2 years ahead & 3 years ahead \\
\hline SGP5yr & 0.000908 & -0.386 & -0.366 \\
& $(0.426)$ & $(0.532)$ & $(0.543)$ \\
SGP5yrdevinter & -0.000301 & 0.146 & 0.025 \\
& $(0.115)$ & $(0.201)$ & $(0.230)$ \\
Constant & 0.229 & $0.856^{* * *}$ & $1.586^{* * *}$ \\
Observations & $(0.237)$ & $(0.272)$ & $(0.339)$ \\
R & 398 & 300 & 179 \\
RMSE & 0.000 & 0.008 & 0.002 \\
\hline
\end{tabular}


Appendix Table 3(b): GDP growth rate forecast error, full dataset

\begin{tabular}{lccc}
\hline Variables & $\mathbf{1}$ year ahead & 2 years ahead & 3 years ahead \\
\hline SGP5yr & 0.042 & 0.451 & $2.430^{*}$ \\
& $(0.431)$ & $(0.931)$ & $(1.320)$ \\
SGP5yrdevinter & $0.466^{* * *}$ & $0.968^{* * *}$ & $1.060^{* *}$ \\
& $(0.100)$ & $(0.337)$ & $(0.434)$ \\
Constant & $0.408^{* * *}$ & $1.156^{* * *}$ & $1.787^{* * *}$ \\
& $(0.137)$ & $(0.180)$ & $(0.301)$ \\
Observations & 368 & 282 & 175 \\
R $^{2}$ & 0.056 & 0.127 & 0.102 \\
RMSE & 2.341 & 3.289 & 3.866 \\
\hline
\end{tabular}

Appendix Table 3(c): Budget balance forecast error as a \% of GDP, European countries

\begin{tabular}{lccc}
\hline Variables & $\mathbf{1}$ year ahead & 2 years ahead & 3 years ahead \\
\hline SGP5yr & -0.481 & -0.816 & -0.560 \\
& $(0.433)$ & $(0.521)$ & $(0.510)$ \\
SGP5yrdevinter & -0.000301 & 0.146 & 0.025 \\
& $(0.116)$ & $(0.202)$ & $(0.231)$ \\
Constant & $0.711^{* * *}$ & $1.287^{* * *}$ & $1.779^{* * *}$ \\
& $(0.240)$ & $(0.294)$ & $(0.311)$ \\
Observations & 254 & 221 & 164 \\
R $^{2}$ & 0.007 & 0.019 & 0.005 \\
RMSE & 2.296 & 3.046 & 3.234 \\
\hline
\end{tabular}

Appendix Table 3(d): GDP growth rate forecast error, European countries

\begin{tabular}{lccc}
\hline Variables & 1 year ahead & 2 years ahead & 3 years ahead \\
\hline SGP5yr & -0.180 & 0.196 & $2.351^{*}$ \\
& $(0.442)$ & $(0.943)$ & $(1.321)$ \\
SGP5yrdevinter & $0.466^{* * *}$ & $0.968^{* * *}$ & $1.060^{* *}$ \\
& $(0.101)$ & $(0.339)$ & $(0.435)$ \\
Constant & $0.629^{* * *}$ & $1.412^{* * *}$ & $\left(.867^{* * *}\right.$ \\
& $(0.120)$ & $(0.206)$ & 164 \\
Observations & 248 & 219 & 0.104 \\
R $^{2}$ & 0.078 & 0.139 & 3.952 \\
RMSE & 2.470 & 3.593 & \\
\hline
\end{tabular}

\section{References}

Alesina, A., and Perotti, R. (1995), 'The Political Economy of Budget Deficits', Staff Papers International Monetary Fund, 42(1), March, 1-31.

_ _ (1996), 'Fiscal Discipline and the Budget Process', American Economic Review, 86(2), Papers and Proceedings, May, 401-7.

— Tabellini, G. (1990a), 'Voting on the Budget Deficit', American Economic Review, 80(1).

_ _ (1990b), 'A Positive Theory of Fiscal Deficits and Government Debt', Review of Economic Studies.

- Campante, F., and Tabellini, G. (2008), 'Why is Fiscal Policy Often Procyclical?', Journal of the European Economic Association, 6(5), September, 1006-36. 
Alesina, A., Perotti, R., and Tavares, J. (1998), 'The Political Economy of Fiscal Adjustments', Brookings Papers on Economic Activity, 28(1), 197-248.

- Hausmann, R., Hommes, R., and Stein, E. (1999), 'Budget Institutions and Fiscal Performance in Latin America', Journal of Development Economics, 59, 253-73.

Arezki, R., and Brückner, M. (2010), 'International Commodity Price Shocks, Democracy, and External Debt', IMF Working Paper 10/53, Washington, DC, International Monetary Fund.

- Ismail, K. (2010), 'Boom-Bust Cycle, Asymmetrical Fiscal Response and the Dutch Disease', IMF WP/10/94, Washington, DC, International Monetary Fund, April.

Ashiya, M. (2007), 'Forecast Accuracy of the Japanese Government: Its Year-ahead GDP Forecast is Too Optimistic', Japan and the World Economy, 19(1), January, 68-85.

Auerbach, A. (1994), 'The US Fiscal Problem: Where We are, How We Got Here and Where We're Going', NBER Macroeconomics Annual 1994, Vol. 9, 141-86; NBER WP No. 4709.

- (1999), 'On the Performance and Use of Government Revenue Forecasts', National Tax Journal, 52(4), $765-82$.

Beetsma, R., and Giuliodori, M. (2010), 'Fiscal Adjustment to Cyclical Developments in the OECD: An Empirical Analysis Based on Real-time Data', Oxford Economic Papers, 62(3), 419-41, July.

- - Wierts, P. (2009), 'Planning to Cheat: EU Fiscal Policy in Real Time', Economic Policy, 24(60), 753-804.

- Bluhm, B., Giuliodori, M., and Wierts, P. (2011), 'From First-release to Ex-post Fiscal Data: Exploring the Sources of Revision Errors in the EU', University of Amsterdam, May, mimeo.

— Giuliodori, M., Walschot, M., and Wierts, P. (2010), 'Fifty Years of Fiscal Planning and Implementation in the Netherlands', CEPR Discussion Paper No. 7969, Centre for Economic Policy Research, August.

Brück, T., and Stephan, A. (2006), 'Do Eurozone Countries Cheat with their Budget Deficit Forecasts?', Kyklos, 59(1), 3-15.

Buchanan, J. (1967), Public Finance in Democratic Process: Fiscal Institutions and Individual Choice, Chapel Hill, NC, University of North Carolina Press.

Calderón, C., and Schmidt-Hebbel, K. (2003), 'Macroeconomic Policies and Performance in Latin America', Journal of International Money and Finance, 22(7), 895-923.

- - (2008). 'Business Cycles and Fiscal Policies: The Role of Institutions and Financial Markets', Working Paper 481, Central Bank of Chile.

- Duncan, R., and Schmidt-Hebbel, K. (2010), 'Institutions and Cyclical Properties of Macroeconomic Policies in the Global Economy', Documentos de Trabajo 372, Instituto de Economia, Pontificia Universidad Católica de Chile.

Cárdenas, M., Mejía, C., and Olivera, M. (2009), 'The Political Economy of the Budget Process in Colombia', in M. Hallerberg, C. Scartascini, and E. Stein (eds), Who Decides the Budget, A Political Economy Analysis of the Budget Process in Latin America, IDB and David Rockefeller Center for Latin American Studies, Harvard University.

Cuddington, J. (1989), 'Commodity Export Booms in Developing Countries', World Bank Research Observer, 4, 143-65.

Davis, J., Ossowski, R., Daniel, J., and Barnett, S. (2001), 'Oil Funds: Problems Posing as Solutions?', Finance and Development, 38(4), Washington, DCInternational Monetary Fund.

_ _ _ _ (2003), 'Stabilization and Savings Funds for Nonrenewable Resources: Experience and Fiscal Policy Implications', in J. Davis, R. Ossowski, and A. Fedelino (eds), Fiscal Policy Formulation and Implementation in Oil-Producing Countries, Washington, DC, International Monetary Fund.

Engel, E., Neilson, C., and Valdés, R. (2011), 'Chile's Structural Balance Rule as Social Policy', Central Bank of Chile Working Paper 627, May.

Forni, L., and Momigliano, S. (2004), 'Cyclical Sensitivity of Fiscal Policies Based on Real-time Data', Economic Research Department, Temi di Discussione No. 540, Bank of Italy.

Frankel, J. (2003), 'Republican and Democratic Presidents Have Switched Economic Policies', Milken Institute Review, 5(1), 18-25.

- (2008), 'Snake-oil Tax Cuts', Briefing Paper 221, Washington, DC, Economic Policy Institute.

- (2011), 'A Solution to Fiscal Procyclicality: The Structural Budget Institutions Pioneered by Chile', forthcoming in L. F. Céspedes and J. Galí (eds), Fiscal Policy and Macroeconomic Performance, Series 
on Central Banking, Analysis, and Economic Policies, Central Bank of Chile Working Paper 604, January.

Frendreis, J., and Tatalovich, R. (2000), 'Accuracy and Bias in Macroeconomic Forecasting by the Administration, the CBO, and the Federal Reserve Board', Polity, 32(4), 623-32.

Galí, J., and Perotti, R. (2003), 'Fiscal Policy and Monetary Integration in Europe', Economic Policy, 37, 533-72.

Gavin, M., and Perotti, R. (1997), 'Fiscal Policy in Latin America', NBER Macroeconomics Annual, Vol. 12, 11-61.

Gelb, A. (1986), 'Adjustment to Windfall Gains: A Comparative Analysis of Oil-Exporting Countries', in J. P. Neary and S. van Wijnbergen (eds), Natural Resources and the Macroeconomy, Cambridge, MA, MIT Press, 54-93.

Grilli, V., Masciandaro, D., and Tabellini, G. (1991), 'Political and Monetary Institutions and Public Financial Policies in the Industrial Countries', Economic Policy, 6(13), 341-92.

Ilzetski, E., and Vegh, C. (2008), 'Procyclical Fiscal Policy in Developing Countries: Truth or Fiction?', NBER Working Paper No. 14191.

Jonung, L., and Larch, M. (2006), 'Improving Fiscal Policy in the EU: The Case for Independent Forecasts', Economic Policy, 21(47), 491-534.

Kaminsky, G., Reinhart, C., and Vegh, C. (2005), 'When It Rains, It Pours: Procyclical Capital Flows and Macroeconomic Policies', NBER Macroeconomics Annual 2004, Vol. 19, 11-82.

Lane, P. (2003), 'The Cyclical Behaviour of Fiscal Policy: Evidence from the OECD', Journal of Public Economics, (12), 2661-75.

Marinheiro, C. (2008), 'The Stability and Growth Pact, Fiscal Policy Institutions and Stabilization in Europe', International Economics and Economic Policy, 5(1), 189-207.

- (2010), 'Fiscal Sustainability and the Accuracy of Macroeconomic Forecasts: Do Supranational Forecasts Rather than Government Forecasts Make a Difference?', GEMF Working Papers 2010-07, Faculdade de Economia, Universidade de Coimbra; forthcoming in International Journal of Sustainable Economy.

McNab, R. M., Rider, M., and Wall, K. (2007), 'Are Errors in Official US Budget Receipts Forecasts Just Noise?', Andrew Young School Research Paper Series Working Paper 07-22, April.

McNees, S. (1995), 'An Assessment of the “'Official' Economic Forecasts', New England Economic Review, July/August.

Medas, P., and Zakharova, D. (2009), 'Primer on Fiscal Analysis in Oil-Producing Countries', IMF Working Paper 56, March.

Mendoza, E. G., and Oviedo, P. M. (2006), 'Fiscal Policy and Macroeconomic Uncertainty in Developing Countries: The Tale of the Tormented Insurer', NBER Working Paper No. 12586, October.

Mühleisen, M., Danninger, S., Hauner, D., Krajnyák, K., and Sutton, B. (2005), 'How Do Canadian Budget Forecasts Compare With Those of Other Industrial Countries?', IMF Working Paper 05/66, April.

Neut, A., and Velasco, A. (2003), 'Tough Policies, Incredible Policies?', NBER Working Paper No. 9932, September.

O’Neill, T. (2005), Review of Canadian Fiscal Forecasting: Processes and Systems, Department of Finance, Canada, June, available at http://www.fin.gc.ca/toc/2005/oneil_-eng.asp

Ossowski, R., Villafuerte, M., Medas, P., and Thomas, T. (2008), 'Managing the Oil Revenue Boom: The Role of Fiscal Institutions', Occasional Paper No. 260, Washington, DC, International Monetary Fund.

Persson, T., and Tabellini, G. (2002), 'Political Economics and Public Finance', Handbook of Public Economics, Vol. 3, ch. 24, 1549-659.

_ - (2004), 'Constitutional Rules and Fiscal Policy Outcomes', American Economic Review, 94(1), $25-45$

Poterba, J. (1997), 'Do Budget Rules Work?', in A. Auerbach (ed.), Fiscal Policy: Lessons From Empirical Research, Cambridge, MA, MIT Press, 53-86.

- von Hagen, J. (eds) (1999), Fiscal Institutions and Fiscal Performance, Chicago, IL, University of Chicago Press.

Roubini, N., and Sachs, J. (1989a), 'Government Spending and Budget Deficits in the Industrial Economies', Economic Policy, 8, April.

- - (1989b), 'Political and Economic Determinants of Budget Deficits in the Industrial Democracies', European Economic Review, 33(5), 903-33. 
Stein, E., Talvi, E., and Grisanti, A. (1999), 'Institutional Arrangements and Fiscal Performance: The Latin American Experience', in J. Poterba and J. von Hagen (eds), Fiscal Institutions and Fiscal Performance, Chicago, IL, University of Chicago Press.

Strauch, R., Hallerberg, M., and von Hagen, J. (2009), 'How Forms of Fiscal Governance Affect Fiscal Performance', in M. Hallerberg, R. Strauch, and J. von Hagen (eds), Fiscal Governance in Europe, Cambridge, Cambridge University Press; revised version of Von Hagen et al. (2004).

Talvi, E., and Vegh, C. (2005), 'Tax Base Variability and Procyclicality of Fiscal Policy', Journal of Development Economics, 78(91), 156-90.

Tornell, A., and Lane, P. (1999), 'The Voracity Effect', American Economic Review, 89(1), 22-46.

von Hagen, J., and Harden, I. (1995), 'Budget Processes and Commitment to Fiscal Discipline', European Economic Review, 39(3-4), 771-9.

- Hallerberg, M., and Strauch, R. (2004), 'Budgetary Forecasts in Europe-The Track Record of Stability and Convergence Programmes', ECB WP No. 30.

Wyplosz, C. (2005), 'Fiscal Policy: Institutions versus Rules', National Institute Economic Review, 191(1); also CEPR Discussion Papers no. 3238. 